\title{
A REVIEW OF CHEMICAL LEACHING OF COAL BY ACID AND ALKALI SOLUTION
}

\author{
S.K. Behera ${ }^{1 \#}$, U. Kumari ${ }^{1}$, B.C. Meikap ${ }^{1,2}$ \\ ${ }^{1}$ Indian Institute of Technology (IIT) Kharagpur, Department of Chemical Engineering, \\ West Bengal-721302, India \\ ${ }^{2}$ Chemical Engineering, School of Engineering, Howard College, University of Kwazulu-Natal \\ (UKZN), Durban 4041, South Africa
}

(Received: March 3, 2018; Accepted: June 11, 2018)

\begin{abstract}
Low rank or low-grade (LRC or LGC) coals are most abundant distribute around the several regions in the world. The contribution of low-rank coal is a significant role in the energy sectors and chemical feedstock to the industries. The hard coal reserves are gradually depleting, and the mining operation at deeper coal seam with greater difficulties as well as the cost of exploration is so high, which has a significant issue for plant economics. Therefore, the low-grade coal can be used as an alternative energy source to minimize these problems. Low-rank coals are usually associated with high mineral matter and moisture content, which exerts substantial impacts on their consumption including pyrolysis, liquefaction, gasification and combustion process. In order to understand the essential treatment of coal for efficient removal of mineral matters and improve coal properties by beneficiation techniques are crucial to developing advanced technologies. The present article provides a comprehensive overview of the various processes concerning demineralization of coal by chemical beneficiation technique. It has been found from the study; the degree of demineralization was greater in chemical beneficiation compared to physical beneficiation. It is because the chemical reagents are attacked to the interior of coal which removes the inorganic materials and finely dispersed minerals from the coal matrix. The chemical methods have separated all types of minerals from the coal matrix. However, the separation of minerals by the physical method depends on the mineral properties. Chemical beneficiation is an appropriate method to reduce both organic and inorganic mineral constituents from the LGC by leaching method. The chemical reagents are diffusing to the interior of coal matrix through the pores and subsequently dissolute the minerals. Throughout the study challenges, the chemical cleaning of low-grade coal has been efficient techniques for reducing the minerals to a minimum level that can be upgraded to high rank coal.
\end{abstract}

Key words: low grade coal; mineral matter; beneficiation; chemical method; demineralization.

\section{Introduction}

Coal is the world's most prevalent and abundantly distributed fossil fuel. Coal has to continue being to contribute as an energy source, aid global efforts, eradicate poverty, expand economic growth and meet climate change goals. Coal plays a vital role in power production and as a feed to the iron, cement and steel industries, etc. The utilization of coal in different purposes results in the emission of a large quantity of solids, and gaseous pollutants like $\mathrm{CO}_{2}, \mathrm{SO}_{\mathrm{X}}, \mathrm{NO}_{\mathrm{x}}$ and other noxious compounds [1-3]. Coal plays a vital role in power production and as a feed to the iron, cement and steel industries, etc. From IEA report 2012, it has been observed that out of total resources in the world, accounting $64 \%$ of recoverable fossil resources, compared to $19 \%$ for oil and $17 \%$ for natural gas [4]. According to International Energy Outlook, 2016 [5] coal remains the

\#Corresponding author: skbehera@che.iitkgp.ac.in 
second-largest energy source worldwide behind petroleum and other fuels. Throughout the estimation, more than $70 \%$ of world coal used by the top three countries are China, the United States, and India. The world coal consumption out of total coal in 2012 about $59 \%$ is accounted for generation of electricity, $36 \%$ accounted for the industrial sector, and $4 \%$ used other sectors (residential and commercial). The world's energy consumption is purely correlated with the global economic growth.

The hard coal reserves are gradually depleting, and the mining operation at deeper coal seam with greater difficulties and cost of exploration is so high, which has a significant issue for plant economics. The low grade coal can be used as alternative source to eradicate the energy caused issues. Low-grade coals or low quality coals include not only low rank coals (sometimes called brown coals). Lowgrade coals could be important to both the energy demand and economic development for the industries. However, the low-rank coals have not been utilized to nearly the same extent as higher rank coals due to its poor quality and undesirable characteristics. The undesirable characteristics of low grade coals are mainly produces high ash content (typically ranging from $30 \%$ to $50 \%$ ), low sulfur content $(0.2 \%$ to $0.7 \%)$, high moisture content (typically ranging $4 \%$ to $20 \%$ ), low calorific values (between 2500 and 5000 $\mathrm{kcal} / \mathrm{kg}$ ), low Hardgrove Grindability Index (HGI), express to high milling power consumption and increased mill wear and maintenance costs [6]. Although the low quality coals have a huge potential for providing an affordable and abundant energy resource, so it can be used as feedstock instead of high rank coal. In some places of India like northeast region, have found the better quality of coal which contains very low ash content (around 5-10\%) but these coals contain high sulfur content (2-5\%). Low rank/grade coal (LRCs or LGCs) have low specific energy because the coal incorporates with various mineral in different forms. Indian coals are drift origin and have greater drawbacks. The presence of mineral constituents in the LGCs are not only high but also closely associated with different type of minerals in the coal matrix. According to mineralogical analysis, the occurrence of mineral matter in the Indian coal found the various form of silica (quartz, opal, cherts), clay minerals (kaolinite and illite) and sulfide type. It restricts to large-scale utilization and processing in various units due to presence of high ash and sulfur content in the LGCs by according to environmental concern. On the other hand, it has a number of advantageous characteristics such as (i) low phosphorus and sulfur content $(<1 \%)$, (ii) high ash fusion temperature $\left(1500{ }^{\circ} \mathrm{C}\right)$, (iii) low iron content in the ash, (iv) low chlorine content, (v) low trace elements, (vi) refractory nature of the ash [7]. Therefore, it is necessary to demineralize and desulfurize the LGC prior to utilization by reducing the minerals and to make them environment friendly and consequently cost-effective. Efficient coal cleaning method is key to any utilization routes for low-grade coals. There are some upgrading technologies used for cleaning of coals. There are different types of coal cleaning methods present like physical, chemical and biological cleaning method. The physical cleaning methods are mainly dry cleaning and wet cleaning type. The dry cleaning methods include the air jig, aerodynamic classifier, electrodynamics separator, magnetic separator, air-dense medium fluidized bed and the FGX separator etc. These coal cleaning methods are based on according to the difference in physical properties between the coal and refuse. The physical properties of coal cleaning are like density, size, electrical and magnetic conductivity, radioactivity and the frictional 
coefficient. Similarly, wet cleaning methods are mainly based on their specific gravity and surface properties of coal and coal-bearing minerals. The cleaning of coarse coal particles are used the dense medium (specific gravity typically ranges between 1.3 and 1.8), the intermediate coal particle $(0.6-6.35 \mathrm{~mm})$ used water only hydrocyclone and for fine coal particle used froth flotation process or oil agglomeration. The surface properties of the coal minerals are mainly followed the difference in hydrophobicity or oleophobicity between coal and minerals. Naturally, the hard coals are hydrophobic, oleophilic, while minerals are mostly hydrophilic, or oleophobic. When the collectors (oily or frothers) are added into a coal-water slurry, preferentially coals are attach to air-filled froth bubbles or oil droplets, while minerals are as reject with air or oil. These separation principles are difference of the slightly hydrophobic pyrite minerals and the oiladsorbing clay minerals. The current commercial physical cleaning methods are become inefficient separation for the inherent bound minerals to the coal matrix and accordingly more expensive. Besides, the physical cleaning of coal is ineffective to separate the sulfur or finely dispersed mineral and organically bound to the coal structure. The other separation method for of the minerals from coal is the biological cleaning method which have the potential for removing substantial amount of both minerals and organic sulfur, but the separation process is very slow. Therefore, the above reason caused the inefficient to separation of minerals by the physical and biological methods. The lowgrade coals are incorporated with the significant fraction of the inorganic constituents and finely dispersed into the organic structure. Consequently, many conventional coal cleaning methods provide little or no benefit when applied to low grade coals. Therefore, the chemical method is one of the best method for effective removal of both organic and inorganic minerals from coal. The leaching process is faster for liberation of minerals and which directs affect the coal minerals without harm to the original structure of coal.

The chemical cleaning of coal method adequately reduces ash content and remove the deleterious minerals which avoid problems associated with gasification, carbonization, liquefaction, combustion efficiencies and minimize the emissions of airborne pollutants. This is the real situation for both old and new coal cleaning technologies. The physical methods are not suitable to coals for inherent ash-related minerals and are finely disseminated minerals in the coal matrix. In contrast, the chemical cleaning methods are more suitable to remove both organic and inorganic ash-bearing minerals efficiently from coal. Due to this, chemical cleaning of coal is an alternative technique to physical cleaning; allowing for achieving the efficient ash removal rates that cannot be achieved in the physical cleaning. The several literature studies revealed the great potential for chemical cleaning of coals, with better ash removal was obtained from the coal. Chemical cleaning method has not widely employed on a commercial scale due to huge cost related to the requirements of chemicals and the need for dewatering of the post-demineralization and regeneration of reagents from spent solution [8-10]. It can be seen from literature only a few studies about the regeneration of chemical reagents from the spent solution by adding a suitable chemical reagent. . In the regeneration methods, the spent alkali solution can be regenerated by reacting with lime, whereas acid can be regenerated by treating silicic acid $(\mathrm{H} 2 \mathrm{SiO} 3)$, produced with gypsum.

The following possible reactions (1), (2) and (3) occurs during the regeneration of chemical reagents. 


$$
\begin{aligned}
& \mathrm{Na}_{2} \mathrm{SiO}_{3}+\mathrm{Ca}(\mathrm{OH})_{2} \rightarrow 2 \mathrm{CaSiO}_{3}+2 \mathrm{NaOH} \\
& \mathrm{Na}_{2} \mathrm{SiO}_{3}+\mathrm{H}_{2} \mathrm{SO}_{4} \rightarrow \mathrm{H}_{2} \mathrm{SiO}_{3}+\mathrm{Na}_{2} \mathrm{SO}_{4} \\
& \mathrm{H}_{2} \mathrm{SiO}_{3}+\mathrm{CaSO}_{4} \rightarrow \mathrm{CaSiO}_{3}+\mathrm{H}_{2} \mathrm{SO}_{4}
\end{aligned}
$$

Regeneration of spent alkali and acids reduces the cost of chemicals in the cleaning method. The spent solution which contain not only silicate and aluminates but also contains $\mathrm{Fe}, \mathrm{Al}$, and trace elements of $\mathrm{Zn}, \mathrm{Cr}, \mathrm{Mn}, \mathrm{Ni}$, $\mathrm{Cu}, \mathrm{Ba}, \mathrm{Ti}$ etc. The regenerated reagents from spent solution can be reused which is likely to be the best way to develop a commercial process for removal of minerals from the coal.

Several researchers have been worked on the cleaning of coal by chemical leaching method, which proved that the efficient demineralization was obtained by chemical beneficiation method. The objective of the current review article represents a comprehensive knowledge of different leaching process; the possible reaction occurs during leaching of minerals in the coal with various aqueous chemical reagents and the effect of physical parameters, which can be magnified the degree of demineralization. The concept and understanding of leaching, which allows the calculations to make on; how specific coal may act under certain leaching conditions and follow an optimum leaching sequence. The leaching techniques can be customized to different coal and subsequent scaled-up the processes can be used to study a pilot and large scale. The suitable method and processes can further be applied to the development of approaches for the retrieval of leaching reagents from the spent solution.

\section{Mineral matters in coal}

Coal is a sedimentary rock and is composed of three categories of substances: (1) organic carbonaceous matter called macerals, (2) inorganic (crystalline type) minerals which are non-combustible resulted in the ash formation and (3) fluids. The fluid occurs in between solid constituents or inside pore of the coal. Prior to mining, the fluids in coal are mainly moisture and methane. The term mineral matter is comprehensive of inorganic elements bonded with the various ways to the organic $(\mathrm{C}, \mathrm{H}, \mathrm{O}, \mathrm{N}, \mathrm{S})$ components. There are various species of minerals bound to the coal structure. However, the most common mineral species found in the coal are clay minerals, which distribute widely and are major content in the coal matrix. Comparatively the common minerals found in the coals are silica, quartz, pyrite, calcite, dolomite, siderite, and ankerite, etc. The mode of occurrence and aggregates of minerals in coal seam appears in the form of dispersed grains, nodules, and bands. In maceral, the presence of mineral species is in scatter and smaller than several microns. The coal associated mineral matter exists in various forms and sizes, like true minerals, dissolved salts in pore water and elements associated with hydrocarbonaceous matrix and are micro sizes [11]. The origins and the formation of minerals or ages are co-existed different in the same seam. The minerals in the coal are the geochemical indicator of coal. The petrographic and mineralogical methods are employed for identification and separation of minerals from the coal, and also chemical analytical methods are used to analyze the trace elements in coal. The minerals in the coal are the important factor for quality of coal which assessing mining exploration, communition, storage, coking, gasification, liquefaction, and other application. Coal with a high content of mineral matters is the source of metals and nonmetals, which is the serious cause of the environmental problem.

Mineral matter in coal is broadly classified into two types, extraneous and inherent or included minerals. The minerals in coal also exist in different forms like discrete type, dispersed type and organically bounded type as shown in Figure 1. 


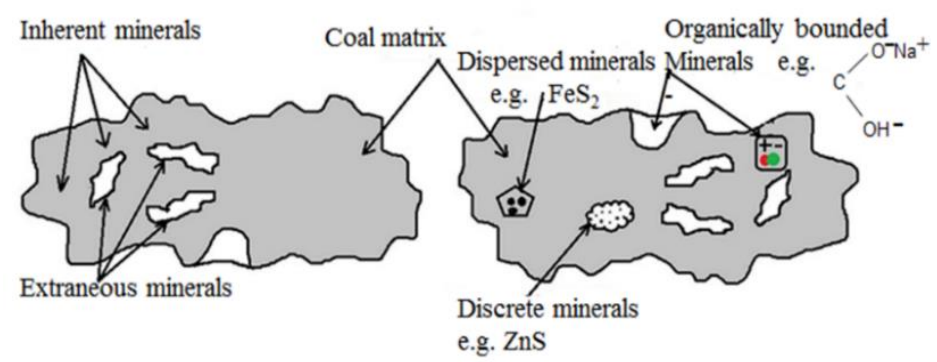

Figure 1. Modes of occurrence of minerals and other constituents in coal [15]

The included minerals are bound to coal matrix or structure; such minerals are clay quartz, carbonate and pyrite group and those minerals are not associated or bounded to coal matrix called extraneous or excluded mineral matter. The extraneous mineral matter is due to contamination occurred during coalification, mining and handling of coal [12-14]. The rank of coal plays a key role in mineral characteristics and properties of the matter. A large number of minerals that have been recognized in the coals over world-wide have wide-range of applications in the instrumental and microscopic techniques. The list of minerals in coal is summarized as shown in Table 1. The presence of inorganic components in higher rank coal is found in the form of mineral phases like illite, chlorite, dolomite, siderite and to some extent kaolinite, quartz and iron oxides. Whereas, the presence of inorganic components in the lower rank coals are associated with discrete mineral phase, coordinated metal ions (cations) or in clay. The major mineral found in lower rank coals includes carbonates, montmorillonite (clay particle), calcite, feldspars, pyrite, and metal sulphate. The major components of silica, alumina is found in clay or kaolinite minerals, silicon found in quartz. The organic mineral components of coal consist of carboxylic acid, phenolic hydroxyl, mercapto and amino groups are able to bond with several mineral constituents.

Coal contains mineral matter, not 'ash,' but ash is widely used term that measures the residue, in which the inert mineral matter of both organic and inorganic parts of coal is chemically changed during combustion. The conventional physical methods are widely used in large-scale units to remove ashbearing mineral from the coal matrix, but the degree of demineralization is up to a certain limit. The high ash content (minerals) of coal leads to technical difficulties in utilization, and it produces a lot of ash. That causes pollute the environment and simultaneously reduce the efficiency resulted increased the production cost of the industries. Many problems are arises due to the large utilization of high ash coal includes more amount of ash disposal, fouling of economizers, corrosion of boiler walls, and high amount of fly ash emission. It may also be a source of abrasion, corrosion, stickiness, fouling, or pollute to the environment by the generation of solids or gaseous pollutants during coal handling and use [16-18].

Coal ash also called coal combustion product consists of fine particles, which contain an assortment of minerals such as clays, quartz, iron oxides, aluminosilicate formed by melting of mineral matter at the high temperatures of combustion, and unburned carbon remains after the combustion process. The mineralogical analysis of coal indicates the mineral in the coal is not uniform. The number of trace elements is intimately associated with the organic matter [19], and mostly the trace elements are associated with major minerals like quartz, 
pyrites, kaolinite, and illite [20-21]. The ash forming behaviour of mineral phases in the coal varies with cleaning method. Trace element in a coal is an important role for formation ash [22-23] while some of the trace elements may mix in the environment with ash leaching [24-25]. The degree of ash content depends on the concentration of trace elements as well as major mineral contents of coal.

Table 1. Different minerals found in coal [28-30]

\begin{tabular}{|c|c|c|c|c|}
\hline \multirow[t]{2}{*}{ Minerals } & \multirow[t]{2}{*}{ Composition } & \multicolumn{3}{|c|}{ Occurrence } \\
\hline & & $\begin{array}{c}\text { Abun } \\
\text { dant } \\
(\checkmark)\end{array}$ & $\begin{array}{l}\text { Comm } \\
\text { on }(\star)\end{array}$ & $\operatorname{Rare}(\downarrow)$ \\
\hline \multicolumn{5}{|l|}{ Clay } \\
\hline Kaolinite & $\mathrm{AI}_{4} \mathrm{Si}_{4} \mathrm{O}_{10}(\mathrm{OH})_{8}$ & $\checkmark$ & & \\
\hline $\begin{array}{l}\text { Montmorilloni } \\
\text { te }\end{array}$ & $\mathrm{Al}_{4}\left(\mathrm{Si}_{4} \mathrm{O}_{10}\right)_{2}(\mathrm{OH})_{4} \times \mathrm{xH}_{2} \mathrm{O}$ & & $\star$ & \\
\hline $\begin{array}{l}\text { Illite, sericite, } \\
\text { muscovite }\end{array}$ & $\mathrm{K}_{2} \mathrm{Al}_{4}\left(\mathrm{Si}_{6} \mathrm{AI}_{2}\right) \mathrm{O}_{20}(\mathrm{OH})_{4}$ & & $\star$ & \\
\hline Halloysite & $\mathrm{Al}_{4} \mathrm{Si}_{4} \mathrm{O}_{10}(\mathrm{OH})_{8}$ & & & $\downarrow$ \\
\hline Chlorite & $\mathrm{Mg}_{5} \mathrm{Al}\left(\mathrm{AlSi}_{3} \mathrm{O}_{10}\right)(\mathrm{OH})_{8}$ & & & $\downarrow$ \\
\hline $\begin{array}{l}\text { Mixed layer } \\
\text { clay minerals }\end{array}$ & variable & & $\star$ & \\
\hline \multicolumn{5}{|l|}{ Sulfide } \\
\hline Pyrite & $\mathrm{FeS}_{2}$ & & $\star$ & \\
\hline Marcasite & $\mathrm{FeS}_{2}$ (orthorhombic) & & $\star$ & \\
\hline $\begin{array}{l}\text { Greigite } \\
\text { (melnikovite) }\end{array}$ & $\mathrm{Fe}_{3} \mathrm{~S}_{4}$ & & & \\
\hline Sphalerite & $\mathrm{ZnS}$ & & & $\downarrow$ \\
\hline Galena & $\mathrm{PbS}$ & & & $\downarrow$ \\
\hline Chalcopyrite & $\mathrm{CuFeS}_{2}$ & & & $\downarrow$ \\
\hline Pyrrhotite & $\mathrm{Fe}_{1-\mathrm{x}} \mathrm{S}$ & & & $\downarrow$ \\
\hline Bronite & $\mathrm{Cu}_{5} \mathrm{FeS}_{4}$ & & & $\downarrow$ \\
\hline Millerite & $\mathrm{NiS}$ & & & $\downarrow$ \\
\hline \multicolumn{5}{|l|}{$\begin{array}{l}\text { Oxide } \\
\text { minerals }\end{array}$} \\
\hline Quartz & $\mathrm{SiO}_{2}$ & & $\star$ & \\
\hline halcedony & $\mathrm{SiO}_{2}$ & & & $\downarrow$ \\
\hline Hematite & $\mathrm{Fe}_{2} \mathrm{O}_{3}$ & & & $\downarrow$ \\
\hline Magnetite & $\mathrm{Fe}_{3} \mathrm{O}_{4}$ & & & $\downarrow$ \\
\hline Rutile & $\mathrm{TiO}_{2}$ & & & $\downarrow$ \\
\hline Anatase & $\mathrm{TiO}_{2}$ & & & $\downarrow$ \\
\hline Brookite & $\mathrm{TiO}_{2}$ & & & $\downarrow$ \\
\hline Limonite & $\mathrm{Fe}_{2} \mathrm{O}_{3} \cdot \mathrm{nH}_{2} \mathrm{O}$ & & $\star$ & \\
\hline Goethite & $\mathrm{Fe}_{2} \mathrm{O}_{3} \cdot \mathrm{H}_{2} \mathrm{O}$ & & & $\downarrow$ \\
\hline Lepidocrocite & $\mathrm{Fe}_{2} \mathrm{O}_{3} \cdot \mathrm{H}_{2} \mathrm{O}$ & & & $\downarrow$ \\
\hline Diaspore & $\mathrm{Al}_{2} \mathrm{O}_{3} \cdot \mathrm{H}_{2} \mathrm{O}$ & & & $\downarrow$ \\
\hline \multicolumn{5}{|l|}{$\begin{array}{l}\text { Phosphate } \\
\text { minerals }\end{array}$} \\
\hline $\begin{array}{l}\text { Apatite } \\
\text { (fluorapatite) }\end{array}$ & $\mathrm{Ca}_{5}\left(\mathrm{PO}_{4}\right)_{3}(\mathrm{~F}, \mathrm{Cl}, \mathrm{OH})$ & & & $\downarrow$ \\
\hline Goyazite & $\mathrm{SrAl}_{3}\left(\mathrm{PO}_{4}\right)_{2}(\mathrm{OH})_{5} \cdot \mathrm{H}_{2} \mathrm{O}$ & & & $\downarrow$ \\
\hline Gorceixite & $\mathrm{BaAl}_{3}\left(\mathrm{PO}_{4}\right)_{2}(\mathrm{OH})_{5} \cdot \mathrm{H}_{2} \mathrm{O}$ & & & $\downarrow$ \\
\hline Crandallite & $\mathrm{CaAl}_{3}\left(\mathrm{PO}_{4}\right)_{2}(\mathrm{OH})_{5} \cdot \mathrm{H}_{2} \mathrm{O}$ & & & $\downarrow$ \\
\hline Monazite & $\mathrm{CePO}_{4}$ & & & $\downarrow$ \\
\hline Xenotime & $\mathrm{YPO}_{4}$ & & & $\downarrow$ \\
\hline \multicolumn{5}{|l|}{$\begin{array}{l}\text { Carbonate } \\
\text { minerals }\end{array}$} \\
\hline $\begin{array}{l}\text { Calcite } \\
\text { Dolomite }\end{array}$ & $\begin{array}{l}\mathrm{CaCO}_{3} \\
\mathrm{CaMg}\left(\mathrm{CO}_{3}\right)_{2}\end{array}$ & $\sqrt{ }$ & $\star$ & \\
\hline
\end{tabular}


Table 1. Different minerals found in coal [28-30]. (continue) Siderite $\mathrm{FeCO}_{3}$

Ankerite

(ferroan

(Ca, $\mathrm{Fe}, \mathrm{Mg}) \mathrm{CO}_{3}$

dolomite)

Witherite

$\mathrm{BaCO}_{3}$

Dawsonite

Strontionite

Aragonite

$\mathrm{NaAl}\left(\mathrm{CO}_{2}\right)(\mathrm{OH})$

$\mathrm{SrCO}_{3}$ Magnesite $\quad \mathrm{MgCO}_{3}$

Sulphate

minerals

Barite

Gypsum

Anhydrite

Bassanite

Jarosite

Szomolnokite

Rozenite

Melanterite

Coquimbite

Rosmerite

Mirabilite

Kieserite

Thenardite

Sideronatrite
Hexabydrite

$\mathrm{BaSO}_{4}$

$\mathrm{CaSO}_{4} \cdot 2 \mathrm{H}_{2} \mathrm{O}$

$\mathrm{CaSO}_{4}$

$\mathrm{CaSO}_{4} \cdot 1 / 2 \mathrm{H}_{2} \mathrm{O}$

$(\mathrm{Na}, \mathrm{K}) \mathrm{Fe}_{3}\left(\mathrm{SO}_{4}\right)_{2}(\mathrm{OH})_{6}$

$\mathrm{FeSO}_{4} \cdot \mathrm{H}_{2} \mathrm{O}$

$\mathrm{FeSO}_{4} .4 \mathrm{H}_{2} \mathrm{O}$

$\mathrm{FeSO}_{4} .7 \mathrm{H}_{2} \mathrm{O}$

$\mathrm{Fe}_{2}\left(\mathrm{SO}_{4}\right)_{3} .9 \mathrm{H}_{2} \mathrm{O}$

$\mathrm{FeSO}_{4} \cdot \mathrm{Fe}_{2}\left(\mathrm{SO}_{4}\right)_{3} .12 \mathrm{H}_{2} \mathrm{O}$

$\mathrm{Na}_{2} \mathrm{SO}_{4}-\mathrm{I}_{2} \mathrm{H}_{2} \mathrm{O}$

$\mathrm{MgSO}_{4} \cdot \mathrm{H}_{2} \mathrm{O}$

$\mathrm{Na}_{2} \mathrm{SO}_{4}$

Chloride

$\mathrm{Na}_{2} \mathrm{SO}_{4} \mathrm{Fe}_{2}\left(\mathrm{SO}_{4}\right)_{3} .7 \mathrm{H}_{2} \mathrm{O}$

minerals

$\mathrm{MgSO}_{4} \cdot 6 \mathrm{H}_{2} \mathrm{O}$

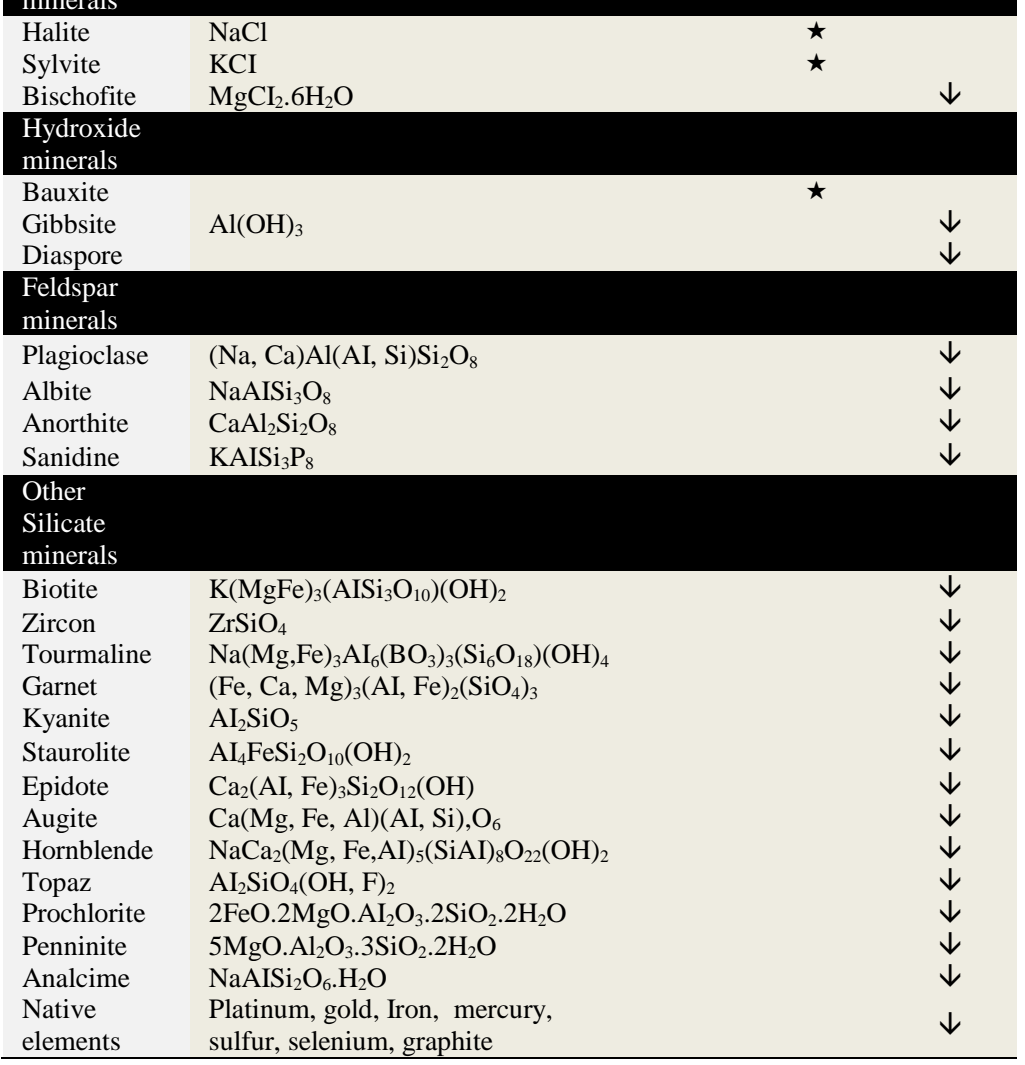


Major chemical constituents of coal ash typically include silicon $(\mathrm{Si})$, aluminum $(\mathrm{Al})$, and iron $(\mathrm{Fe})$, with lesser amounts of oxides of calcium $(\mathrm{Ca})$, magnesium $(\mathrm{Mg})$, potassium $(\mathrm{K})$, sulfur (S), titanium (Ti), and phosphorus $(\mathrm{P})$. The minor amount of trace elements in coal ash, including chromium $(\mathrm{Cr})$, nickel $(\mathrm{Ni})$, zinc $(\mathrm{Zn})$, arsenic (As), selenium (Se), cadmium $(\mathrm{Cd})$, antimony $(\mathrm{Sb})$, mercury $(\mathrm{Hg})$, and lead $(\mathrm{Pb})$ etc. Trace elements are associated with the coal minerals during of its natural formation processes of the parent coal. These inert elements are found in coal ash after combustion of coal. During combustion, most trace elements in the parent coal are retained in the residual coal ash and are concentrated in the smaller volume of the ash compared to the original coal. Trace element concentrations in coal ash are higher compared to the parent coal because of most of the bound minerals and trace elements are directly formed ash after combustion. So, the residual ash contains major and minor mineral with trace elements higher as compared to original coal [26-27]. The affinities of trace elements and minerals in the coal affect the quality of the coal. The organically bounded trace elements are difficult to remove from the coal by cleaning processes such as crushing and washing. Organically bound trace elements may be released only by combustion or by the chemical leaching processes.

Hence, chemical beneficiation is one of the best methods that strongly dissociates or reacts to the bounded mineral in the coal matrix and demineralized to a desirable limit, which generates low ash coal. The produced low ash clean coal by the chemical method is suitable for steel and metallurgical units and reduces the environmental problems.

\section{Coal Beneficiation}

Coal is a complex mixture of organic and inorganic matter to a variable extent depending on its origin, rank and the prevailing environment during coalification process. It is a heterogeneous mixture of organic macerals usually combustible and the inorganic matter most are in mineral form. Coal beneficiation is consist of different operation and processes which can upgrade the quality of coal by reducing the mineral matters (ash) and regulating the size of coal. The mineral matters in the coal called as gangue or impurities, which must be removed before utilization. The objective of beneficiation of coal is to (1) reduce the inert mineral matter (2) improved combustion behavior (3) reducing slagging and fouling characteristics (4) improved by grindability characteristics and compatibility with emission control equipment (5) minimize capital, operating and maintenance costs of coal utilized industries (6) reduce the pollutants and gas emission.

Coal beneficiation technologies are usually classified as physical, chemical and microbial beneficiation techniques. Beneficiation processes are upgrading the quality of coal by reduction of mineral matter (expressed as ash) as well as regulate its size. Physical beneficiation of coal is based on the physical characteristics of coal and impurities. Physical coal cleaning (PCC) can be eliminate the ashforming elements and inorganic sulfur from coal without chemical alteration of the coal or properties. The physical methods of coal beneficiation have a simple operation for separation of coarse impurities but inefficient for removal of ash and sulfur. In a marketable coal preparation plant, the cleaning process is typically limited to physical processes. The separation method of these processes is based upon the difference in the specific gravity (density) and surface properties (wettability) of minerals in the coal. The lumped raw coal is subjected to crushing, sizing and screening, cleaning (washing or beneficiation), and thermal dewatering [31]. However, coal 
cleaning by the physical method is limited to removal all types of mineral and trace elements. Physical treatments are particularly those minerals are in magnetic properties, that removes in magnetic separator and those based on conductivity or electrostatic separator are used to separates the minerals of electric properties [32]. Froth flotation cell is removed only inorganic sulfur whereas organic sulfur removed require by microbial or chemical beneficiation method. It is difficult to reduce the mineral matter to a certain limit by conventional physical beneficiation method. The following drawbacks in conventional physical methods results limited demineralization possible by due to which does not remove the minerals bound to the coal matrix, only inorganic sulfur (pyrite) can be removed. These methods required larger feed size $(>500 \mu \mathrm{m})$ and which is not suitable to demineralize the all types of minerals from the feed coal. These are separated based on the specific gravity and for separation of very fine size, follows surface properties of the mineral matter, which require additional cost for grinding operation. The drift origin of Indian coals are low quality and contains high ash content varies from $15 \%$ to $50 \%$ although the washability characteristics of Indian coal is effectively remove the mineral matter. It is difficult to remove the mineral matter by the washing of such coal is invariably practiced to bring down the ash content to a desirable limit. Low-grade coals are contained major quantity of silica $\left(57 \%, \mathrm{SiO}_{2}\right)$ and alumina $\left(\mathrm{Al}_{2} \mathrm{O}_{3}\right.$, $27 \%$ ). Removal of the extraneous inert and mineral matter from coal prior to combustion is the necessary benefit to the environment as well as the efficiency of operation and process. Reduction of the aluminosilicate clay minerals, which typically $60-90 \%$ of the total mineral matter in coal, are cause to decrease the boiler erosion and fouling, and decrease the amounts of fly ash and bottom ash generated. The high ash in coal causes increase the ash resistivity, reduce the efficiency of equipment and pollutes the environment due to the generation of solids and gaseous pollutant. Therefore, prior to utilization of such coal must be upgrade the coal. The upgrading method of low-grade coal is best by chemical leaching method because these method efficiently removes the inorganic and organic mineral and all type of minerals are dissolute with chemical acids and alkali solution.

\section{Chemical beneficiation of coal}

It is hard to demineralize the low rank coal to below a permissible limit by conventional physical beneficiation techniques due to poor washability characteristics. It is difficult to demineralize the kinds of mineral from coal by a specific chemical reagent or solvent due to an enormous number of mineral associated within the coal matrix. Therefore, to establish a procedure for the production of clean coal and knowledge about the chemical reaction of specific minerals for a particular solvent during the course of leaching. The upgradation of low-grade coal for efficient demineralization by chemical beneficiation follows various method. Chemical beneficiation mainly consists of leaching steps like alkali and acid leaching or combined method alkali and acid leaching. Both steps are formed by mixing the coal with a chemical solvent called slurry is heated up to an experimental temperature which causes the rise in the rate of reaction and consequently leached out the ash-bearing minerals. The leaching of coal with different types of the chemical reagent such as alkali, mineral acid, and some organic acids are most productive in reducing the amount of ash-bearing minerals, inorganic sulfur (pyrite) and organic sulfur (thioketone, thiols, thiophenes, sulfide) without affecting the original carbon content 
of coal. The demineralization of coal by chemical techniques has been investigated by several authors. The leaching of coal with [3334] aqueous $\mathrm{KOH}$-acid solution [35-36] mineral acids like $\mathrm{H}_{2} \mathrm{SO}_{4}$ [37-38] and sequential leaching by $\mathrm{NaOH}-\mathrm{H}_{2} \mathrm{O}_{2} / \mathrm{NaOH}-$ $\mathrm{HCl} / \mathrm{NaOH}-\mathrm{H}_{2} \mathrm{SO}_{4} / \mathrm{NaOH}-\mathrm{HF}$ [39] organic acids like carboxylic acid [40]. Several researchers have been investigated by the raw coal of high and low ash or sulfur treated with different acids or alkali reagents, and these are summarized in Table 2, Table 3 and Table 4.

\subsection{Alkali Leaching}

Alkali leaching is an effective method for demineralization of coal by reducing most of the mineral-rich constituents. It may be due to the synergistic effect of alkali reagents, which have high affinity towards coal minerals and the ability to penetrate the interior of coal matrix. During alkali leaching, alkali reacts with the silica, alumina, and clay-bearing minerals in the coal and reaction product converted into hydrated alkali-bearing silicate, aluminate and aluminosilicate complexes (sodalite) [59]. The reason for attacking the alkali into the major minerals may be due to the presence of hydroxyl ion in the leachants, which has high affinity towards the claybearing minerals [60]. The experimental results found that the degree of demineralization increases steadily as a unction of alkali concentrations up to a certain concentration then the demineralization rates slow down.

Two possible cases may be obtained by the decrease degree of demineralization at higher $\mathrm{NaOH}$ concentration. The first case, the leaching occurs likely due to an initial dissolution of the easily accessible minerals, which occurs at lower $\mathrm{NaOH}$ concentrations. While at higher caustic concentration the leaching starts to affect tightly bound minerals within the coal matrix, these are not easily removed. Therefore, the extent of demineralization was reduced by the rise of $\mathrm{NaOH}$ concentration. The Second case, at higher alkali concentration the coal containing major minerals constituents formed sodium compounds of silicate and aluminate and simultaneously formed aluminosilicates. The following reaction is shown in (4) (5), (6) and (7). The decrease in the degree of demineralization of the coal samples at higher alkali concentration is attributed to formation sodium aluminosilicate formation [61]. It is because the of the silicate and aluminate ions concentration exceeds the solubility product of sodium-aluminosilicate. It may be like the common ion effect of the silicate and aluminate ion. So only formed the sodium complex of a silica-alumina compound like gel type which sticks to coal surface and restricts further demineralization process. The coal surface as shown in Figure 2.

The mechanism of adsorption complex silica to the following possible reactions during leaching process as shown below.

$$
\begin{aligned}
& 2 \mathrm{NaOH}+\mathrm{SiO}_{2} \rightarrow \mathrm{Na}_{2} \mathrm{SiO}_{3}+\mathrm{H}_{2} \mathrm{O} \\
& 2 \mathrm{NaOH}+\mathrm{Al}_{2} \mathrm{O}_{3} \rightarrow 2 \mathrm{NaAlO}_{2}+\mathrm{H}_{2} \mathrm{O} \\
& \mathrm{NaOH}_{(\mathrm{aq})}+\mathrm{NaAl}(\mathrm{OH})_{4(\mathrm{aq})}+\mathrm{Na}_{2} \mathrm{SiO}_{3(\mathrm{aq})} \rightarrow \\
& \left(\mathrm{Na}_{\mathrm{a}}(\mathrm{AlO} 2)_{\mathrm{b}}(\mathrm{SiO} 2) \mathrm{NaOH} . \mathrm{H} 2 \mathrm{O}\right) \\
& \text { Sodium aluminosilicate complex gel } \\
& 2 \mathrm{NaOH}+\text { clay } \rightarrow \text { sodalite }+\mathrm{H}_{2} \mathrm{O} \\
& \mathrm{Ca}(\mathrm{OH})_{2}+\mathrm{SiO}_{2} \rightarrow \mathrm{v}(\mathrm{CaO})_{\mathrm{x}}\left(\mathrm{SiO}_{2}\right)_{\mathrm{y}}\left(\mathrm{H}_{2} \mathrm{O}\right)_{\mathrm{z}} \\
& \mathrm{Ca}(\mathrm{OH})_{2}+\mathrm{Al}_{2} \mathrm{Si}_{2} \mathrm{O}_{5} \rightarrow(\mathrm{CaO})_{\mathrm{x}}\left(\mathrm{Al}_{2} \mathrm{O}_{3}\right)_{\mathrm{y}}\left(\mathrm{SiO}_{2}\right)\left(\mathrm{H}_{2} \mathrm{O}\right)_{\mathrm{Z}}
\end{aligned}
$$

Where $\mathrm{a}, \mathrm{b}, \mathrm{c}$ and $\mathrm{x}, \mathrm{y}, \mathrm{z}$ accordingly in equations (6), (8) and (9) are the stoichiometric coefficient among different element while $\mathrm{R}$ is the hydrocarbon groups in coal matrix. 
Table 2. Demineralization/ desulphurization of some high ash/sulfur coal

\begin{tabular}{|c|c|c|c|c|c|c|c|c|}
\hline $\begin{array}{l}\text { Sl } \\
\text { No. }\end{array}$ & Coal Seams & $\begin{array}{l}\text { Coal type } \\
\text { and ash and } \\
\text { sulphur (\%) }\end{array}$ & $\begin{array}{l}\text { Coal } \\
\text { particle } \\
\text { size ( } \\
\mu \mathrm{m})\end{array}$ & $\begin{array}{l}\text { Chemical } \\
\text { solvent } \\
\text { used }\end{array}$ & $\begin{array}{l}\text { The quantity of } \\
\text { coal and } \\
\text { Solvent } \\
\text { concentration }\end{array}$ & $\begin{array}{l}\text { Physical } \\
\text { parameter } \\
(\mathrm{T}, \mathrm{P}, \mathrm{t})\end{array}$ & $\begin{array}{l}\text { Demineralization/ } \\
\text { Desulfurization } \\
(\%) \\
\text { or Ash\% }\end{array}$ & References \\
\hline 1 & $\begin{array}{l}\text { Indraprastha } \\
\text { thermal power } \\
\text { station and } \\
\text { NTPC, } \\
\text { Badarpur New } \\
\text { Delhi }\end{array}$ & $\begin{array}{l}\text { High ash } \\
(27.5 \% \text { ash } \\
\text { in } \\
\text { Indraprastha } \\
\text { and } 32.3 \% \text { in } \\
\text { NTPC power } \\
\text { plant coal ) }\end{array}$ & $250 \mu \mathrm{m}$ & $\begin{array}{l}\mathrm{NaOH} \text { or } \\
\mathrm{Na}_{2} \mathrm{CO}_{3} \\
\text { or } \\
\mathrm{Ca}(\mathrm{OH})_{2} \\
\text { and } \\
\mathrm{H}_{2} \mathrm{SO}_{4} \text { or } \\
\mathrm{HCl}\end{array}$ & $\begin{array}{l}5 \mathrm{~g} \text { of coal and } \\
100 \mathrm{ml} \text { of } \\
\text { aqueous } \\
\text { solution of } \\
\mathrm{NaOH} \text { or } \\
\mathrm{Na}_{2} \mathrm{CO}_{3} \text { or } \\
\mathrm{Ca}(\mathrm{OH})_{2} \text { and } \\
\text { washing with } \\
10 \% \text { aqueous } \\
\mathrm{H}_{2} \mathrm{SO}_{4} \text { or } \mathrm{HCl}\end{array}$ & $\begin{array}{l}100^{\circ} \mathrm{C}, 60 \\
\min \end{array}$ & $75 \mathrm{wt} \%$ DM & [41] \\
\hline 2 & $\begin{array}{l}\text { Emma mine, } \\
\text { Puertollano, } \\
\text { Spain }\end{array}$ & $\begin{array}{l}\text { Medium } \\
\text { rank coal } \\
(40.6 \% \\
\text { ash,total } \\
\text { sulfur } 1.18 \% \\
\text { and organic } \\
\text { sulfur } \\
0.27 \%)\end{array}$ & $\begin{array}{l}<0.25 \\
\mathrm{~mm}\end{array}$ & $\mathrm{HNO}_{3}$ & $\begin{array}{l}50 \mathrm{~g} \text { of coal and } \\
500 \mathrm{ml} \text { of } 20 \\
\mathrm{wt} \% \mathrm{HNO}_{3}\end{array}$ & $\begin{array}{l}10 \text { to } 90^{\circ} \mathrm{C}, \\
2 \mathrm{hr}\end{array}$ & $\begin{array}{l}90 \% \text { inorganic and } \\
15 \% \text { organic sulfur } \\
\text { removed }\end{array}$ & {$[42]$} \\
\hline 3 & $\begin{array}{l}\text { Western coal } \\
\text { field, Nagpur }\end{array}$ & $\begin{array}{l}\text { High ash } \\
\text { coal }(32.9 \% \\
\text { ash) }\end{array}$ & $\begin{array}{l}\text { Not } \\
\text { reported }\end{array}$ & $\begin{array}{l}\text { Aqueous } \\
\mathrm{NH}_{3} \\
\mathrm{H}_{2} \mathrm{SO}_{4} \\
\text { and } \mathrm{CaF}_{2}\end{array}$ & $\begin{array}{l}50 \mathrm{~g} \text { of coal, } \\
25 \% \text { (w/w) aq. } \\
\mathrm{NH}_{3} \text { followed } \\
\text { by } \mathrm{H}_{2} \mathrm{SO}_{4}, \mathrm{CaF}_{2}\end{array}$ & $\begin{array}{l}350^{\circ} \mathrm{C}, 100 \\
\mathrm{hr}\end{array}$ & $\begin{array}{l}1^{\text {St }} \text { stage: } 70 \% \mathrm{DM} \\
\text { with } \mathrm{NH}_{3} \\
\text { treatment. } \\
2^{\text {nd }} \text { stage: treated } \\
\text { coal followed with } \\
\mathrm{HCl} \text { up to } 13 \% \\
\mathrm{DM}\end{array}$ & [43] \\
\hline 4 & $\begin{array}{l}\text { Asphaltite } \\
\text { samples } \\
\text { Simak and } \\
\text { Hazro, Turkey }\end{array}$ & $\begin{array}{l}\text { High ash } \\
40.8 \% \\
\text { and } 18.8 \% .\end{array}$ & $\begin{array}{l}3.36 \\
0.07 \mathrm{~mm}\end{array}$ & $\begin{array}{l}\text { Acidic } \\
\mathrm{Fe}\left(\mathrm{NO}_{3}\right)_{3} \\
9 \mathrm{H}_{2} \mathrm{O}\end{array}$ & $\begin{array}{l}5 \mathrm{~g} \text { asphaltite } \\
\text { sample mixed } \\
\text { with } 50 \mathrm{ml} \text { of } \\
0.05-1 \mathrm{M} \\
\text { leaching } \\
\text { solution }\end{array}$ & $\begin{array}{l}70-120^{\circ} \mathrm{C}, \\
2-12 \mathrm{~h}\end{array}$ & $\begin{array}{l}72.2 \% \text { sulfur and } \\
96.6 \% \text { pyritic } \\
\text { sulfur removed }\end{array}$ & {$[44]$} \\
\hline 5 & $\begin{array}{l}\text { Amasra } \\
\text { bituminous } \\
\text { coal Turkey }\end{array}$ & $\begin{array}{l}\text { High ash low } \\
\text { sulphur (44- } \\
69 \% \text { ash and } \\
0.21-0.73 \% \\
\text { S) }\end{array}$ & $\begin{array}{l}140-500 \\
\mu \mathrm{m}\end{array}$ & $\begin{array}{l}\mathrm{NaOH}, \\
\mathrm{HF}, \mathrm{HCl}, \\
\mathrm{HNO}_{3}, \\
\text { and } \\
\mathrm{H}_{2} \mathrm{SO}_{4}\end{array}$ & $\begin{array}{l}5 \mathrm{~g} \text { coal, } 10,20 \text {, } \\
30 \%(\mathrm{HF}, \mathrm{HCl}, \\
\mathrm{HNO}_{3} \text { and } \\
\left.\mathrm{H}_{2} \mathrm{SO}_{4}\right) \text {, } \\
\text { washing with } \\
\text { alkali }(0.5 \mathrm{~N} \\
\mathrm{NaOH}) \text { than } \\
\text { followed by } \\
10 \% \text { of } \\
\text { separately } \\
\mathrm{HCl} \mathrm{HNO}_{3}, \\
\left.\mathrm{H}_{2} \mathrm{SO}_{4}\right)\end{array}$ & $20 \mathrm{~min}$ & $\begin{array}{l}46.33 \%, 32.13 \%, \\
30.02 \% \mathrm{DM} \text { in } \\
10 \% \mathrm{HCl}, 10 \% \\
\mathrm{HNO}_{3} \text {, and } 10 \% \\
\mathrm{H}_{2} \mathrm{SO}_{4} \text { respectively }\end{array}$ & {$[45]$} \\
\hline 6 & $\begin{array}{l}\text { High-sulfur } \\
\text { Turkish } \\
\text { lignites }\end{array}$ & $\begin{array}{l}\text { High ash, } \\
(34 \% \text { and } \\
39 \%) \\
\text { High sulfur } \\
(7.6 \text { and } \\
5.2 \% \text { S) }\end{array}$ & $\begin{array}{l}-35 \text { and - } \\
60 \text { mesh }\end{array}$ & $\begin{array}{l}\text { hydrogen } \\
\text { peroxide, } \\
\text { acetic } \\
\text { acid }\end{array}$ & $\begin{array}{l}\text { Desulfurization } \\
\text { (ASTM method } \\
3177 \text { ) }\end{array}$ & $\begin{array}{l}23^{\circ} \mathrm{C}, 50^{\circ} \mathrm{C} \\
104{ }^{\circ} \mathrm{C} \text {, and } \\
72 \mathrm{~h}\end{array}$ & $\begin{array}{l}45 \% \text { and } 85 \% \text { of } \\
\text { sulfur removed } \\
\text { from Geidz and } \\
\text { Cayirhan lignite } \\
\text { sample }\end{array}$ & {$[46]$} \\
\hline 7 & $\begin{array}{l}\text { Nigerian } \\
\text { Lafia-Obi coal }\end{array}$ & $\begin{array}{l}\text { High ash } \\
\text { coal }(32.5 \% \\
\text { ash) }\end{array}$ & $\begin{array}{l} \pm 250 \\
\mu \mathrm{m}\end{array}$ & $\begin{array}{l}\mathrm{H}_{2} \mathrm{O}- \\
\mathrm{Na}_{2} \mathrm{CO}_{3-}^{-} \\
\mathrm{H}_{2} \mathrm{O}\end{array}$ & $\begin{array}{l}3 \mathrm{~g} \text { of coal, } 75 \\
\mathrm{ml} 0.019 \mathrm{M} \text { of } \\
\mathrm{NaOH}, 1: 20 \\
\text { mass ratio of } \\
\text { solvent to coal }\end{array}$ & $\begin{array}{l}95^{\circ} \mathrm{C}, 25 \\
\min \end{array}$ & $38.66 \% \mathrm{DM}$ & [47] \\
\hline 8 & $\begin{array}{l}\text { Bhubaneswari } \\
\text { coal, Orissa. }\end{array}$ & $\begin{array}{l}\text { High ash } \\
\text { coal }(26.25 \% \\
\text { ash) }\end{array}$ & $\begin{array}{l}-16+100 \\
\text { mesh } \\
\text { size }\end{array}$ & $\begin{array}{l}\mathrm{NaOH} \\
\mathrm{H}_{2} \mathrm{SO}_{4}\end{array}$ & $\begin{array}{l}50 \mathrm{~g} \text { of coal } 50 \\
\text { to } 150 \mathrm{~g} / \mathrm{L} \text { of aq. } \\
\mathrm{NaOH} \text { followed } \\
\text { by } 20 \% \mathrm{H}_{2} \mathrm{SO}_{4}\end{array}$ & $\begin{array}{l}1-2 \mathrm{hr} \text {, } \\
\text { temperature } \\
\text { range } 65- \\
150^{\circ} \mathrm{C}\end{array}$ & $\begin{array}{l}27 \% \mathrm{DM} \\
\text { achieved at } 100 \mathrm{~g} / \mathrm{l} \\
\mathrm{NaOH} \\
\text { Concentration, } \\
47 \%-100 \mathrm{~g} / 1 \\
\mathrm{NaOH} \text { followed } \\
20 \% \mathrm{H}_{2} \mathrm{SO}_{4} \text { acid } \\
\text { treatment }\end{array}$ & [48] \\
\hline
\end{tabular}

DM- Demineralization, DS- Desulfurization, T- Temperature $\left({ }^{\circ} \mathrm{C}\right), \mathrm{P}$ - Pressure, t- Time, $\mu \mathrm{m}$ - Micrometer 
Table 3. Demineralization/ desulphurization of some low ash/sulfur coal

\begin{tabular}{|c|c|c|c|c|c|c|c|c|}
\hline $\begin{array}{l}\text { Sl } \\
\text { No } \\
\text {. }\end{array}$ & $\begin{array}{l}\text { Coal } \\
\text { Seams }\end{array}$ & $\begin{array}{l}\text { Coal } \\
\text { type and } \\
\text { ash and } \\
\text { sulphur } \\
(\%)\end{array}$ & $\begin{array}{l}\text { Coal } \\
\text { partic } \\
\text { le } \\
\text { size } \\
(\mu \mathrm{m})\end{array}$ & $\begin{array}{l}\text { Chemic } \\
\text { al } \\
\text { solvent } \\
\text { used }\end{array}$ & $\begin{array}{l}\text { The quantity } \\
\text { of coal and } \\
\text { Solvent } \\
\text { concentration }\end{array}$ & $\begin{array}{l}\text { Physical } \\
\text { parameter } \\
(\mathrm{T}, \mathrm{P}, \mathrm{t})\end{array}$ & $\begin{array}{l}\text { Demineralization/ } \\
\text { Desulfurization }(\%)\end{array}$ & References \\
\hline 1 & $\begin{array}{l}\text { Two } \\
\text { Turkish } \\
\text { lignites } \\
\text { (Beypazari } \\
\text { and } \\
\text { Tunqbilek) }\end{array}$ & $\begin{array}{l}21.39 \% \\
\text { and } \\
16.71 \% \\
\text { ash } \\
\text { respecti } \\
\text { vely }\end{array}$ & $\begin{array}{l}<200 \\
\mu \mathrm{m}\end{array}$ & $\begin{array}{l}\mathrm{H}_{2} \mathrm{O}_{2} \\
0.1 \mathrm{~N} \\
\mathrm{H}_{2} \mathrm{SO}_{4}\end{array}$ & $\begin{array}{l}1:-30 \% \\
\mathrm{H}_{2} \mathrm{O}_{2}, 0.1 \mathrm{~N} \\
\mathrm{H}_{2} \mathrm{SO}_{4} \\
2:-15 \% \\
\mathrm{H}_{2} \mathrm{O}_{2}, 0.1 \mathrm{~N} \\
\mathrm{H}_{2} \mathrm{SO}_{4}\end{array}$ & $\begin{array}{l}1:-30^{\circ} \mathrm{C}, 120 \\
\min \\
2:-45^{\circ} \mathrm{C}, 60 \\
\min \end{array}$ & $\begin{array}{l}\text { 1:- } 70 \% \text { reduction } \\
\text { (Beypazari Lignite) } 35 \\
\% \text { reduction (Tuqbilek } \\
\text { lignite) } 2:-65 \% \\
\text { reduction (Beypazari } \\
\text { Lignite) } 31 \% \\
\text { reduction (Tuqbilek } \\
\text { lignite) }\end{array}$ & [49] \\
\hline 2 & $\begin{array}{l}\text { Subbitumi } \\
\text { nous HV } \\
\text { coal, } \\
\text { Thailand }\end{array}$ & $\begin{array}{l}14.7 \% \\
\text { ash, } \\
4.2 \% \mathrm{~S})\end{array}$ & $\begin{array}{l}500- \\
1000 \\
\mu \mathrm{m}\end{array}$ & $\begin{array}{l}\text { Methan } \\
\text { ol, } \\
\mathrm{KOH}\end{array}$ & $\begin{array}{l}2 \% \text { Methanol } \\
\& 0.025 \mathrm{~g} \\
\mathrm{KOH} / \mathrm{g} \text { coal }\end{array}$ & $\begin{array}{l}150^{\circ} \mathrm{C}, 60 \\
\min \end{array}$ & $\begin{array}{l}58 \% \text { Sulfur and } 24 \% \\
\text { ash } \\
\text { removed }\end{array}$ & [50] \\
\hline 3 & $\begin{array}{l}\text { Khushab } \\
\text { northern } \\
\text { Punjab, } \\
\text { Pakistan }\end{array}$ & $\begin{array}{l}\text { Medium } \\
\text { ash } \\
\text { content } \\
20.4 \% \text {, } \\
2.98 \% \\
\text { sulfur. }\end{array}$ & $\begin{array}{l}212- \\
180 \\
\mu \mathrm{m}\end{array}$ & $\begin{array}{l}\mathrm{HNO}_{3}, \\
\mathrm{HCl} \\
(3 \mathrm{M} \\
\mathrm{HCl}+3 \\
\mathrm{M} \\
\left.\mathrm{HNO}_{3}\right)\end{array}$ & $\begin{array}{l}1 \mathrm{~g} \text { sample } \\
\text { was dropwise } \\
\text { percolated } \\
\text { with different } \\
\text { molar } \\
\text { solution of } \\
100 \mathrm{ml}\end{array}$ & $25^{\circ} \mathrm{C}, 2 \mathrm{hr}$ & $3.09 \%$ ash & [51] \\
\hline 4 & $\begin{array}{l}\text { Ledo (L) } \\
\text { and } \\
\text { Baragolai } \\
\text { (B) } \\
\text { collieries } \\
\text { of Makum } \\
\text { coal fields, } \\
\text { in Assam }\end{array}$ & $\begin{array}{l}10.35 \%, \\
5.70 \% \\
\text { ash and } \\
3.57 \%, \\
5.37 \% \mathrm{~S} \\
\text { in Ledo } \\
\text { and } \\
\text { Baragol } \\
\text { ai coal }\end{array}$ & $\begin{array}{l}-72 \\
\text { mesh }\end{array}$ & Water & $\begin{array}{l}50 \mathrm{~g} \text { coal } \\
\text { samples and } \\
250 \mathrm{~mL} \text { of } \\
\text { deionized } \\
\text { water in a } 1 \mathrm{~L}\end{array}$ & $\begin{array}{l}120 \mathrm{~h} \text { at } \\
\text { varying } \\
\text { temperatures } \\
\text { of } 15,25,35 \text {, } \\
\text { and } 45^{\circ} \mathrm{C}\end{array}$ & $\begin{array}{l}77.59 \% \text { pyritic sulfur } \\
\text { removed with an } \\
\text { aqueous leaching }\end{array}$ & [52] \\
\hline 5 & $\begin{array}{l}\text { Three } \\
\text { mines of } \\
\text { the } \\
\text { Turkish } \\
\text { hard coal } \\
\text { enterprise }\end{array}$ & $\begin{array}{l}6-8.27 \\
\%, \text { low } \\
\text { ash } \\
\text { content, } \\
\text { low } \\
\text { sulfur } 1 \\
\%\end{array}$ & $\begin{array}{l}\text { Not } \\
\text { report } \\
\text { ed }\end{array}$ & $\begin{array}{l}\mathrm{HF}, \mathrm{HN} \\
\mathrm{O}_{3}\end{array}$ & $\begin{array}{l}25 \mathrm{~g} \text { coal } \\
\text { sample and } \\
100 \mathrm{ml} \text { sol of } \\
2 \mathrm{M} \mathrm{HF} \text {, then } \\
\text { dried out in a } \\
\text { drying oven, } \\
\text { second } \\
\text { demineralizati } \\
\text { on } \\
\text { with } 2 \mathrm{M} \\
\mathrm{HNO}_{3}\end{array}$ & $\begin{array}{l}3 \mathrm{hr}, \text { ambient } \\
\text { to } 70^{\circ} \mathrm{C}(\mathrm{HF} \\
\left.\& \mathrm{HNO}_{3}\right) \\
80^{\circ} \mathrm{C} \text { (dried) }\end{array}$ & $\begin{array}{l}\text { Ash content of coal } \\
\text { samples was reduced to } \\
\text { a range of } 0.12-0.41 \%\end{array}$ & [53] \\
\hline 7 & $\begin{array}{l}\text { Yanzhou } \\
\text { (Eastern } \\
\text { China) }\end{array}$ & $\begin{array}{l}3.15 \% \\
\text { ash and } \\
\text { total } \\
\text { sulfur } \\
3.15 \%\end{array}$ & $\begin{array}{l}0.19 \\
\mathrm{~mm}\end{array}$ & $\begin{array}{l}\text { Aeratio } \\
\mathrm{n}+ \\
\mathrm{NaOH} \\
\mathrm{HCl}\end{array}$ & $\begin{array}{l}21 \mathrm{~g} \text { of coal } \\
\text { in } 500 \mathrm{ml} \text { of } \\
0.25 \mathrm{M} \\
\mathrm{NaOH} \text { with } \\
\text { an aeration } \\
\text { rate of } 0.136 \\
\mathrm{~m}^{3} / \mathrm{hr} \text { and } 0.1 \\
\mathrm{~N} \mathrm{HCl} \\
\text { solution }\end{array}$ & $4 \mathrm{~h}$ & $\begin{array}{l}73 \%, 83 \% \text { and } 84 \% \text { of } \\
\text { organic sulfur, sulfide } \\
\text { sulfur pyritic sulfur } \\
\text { removed respectively. }\end{array}$ & [54] \\
\hline
\end{tabular}

DM- Demineralization, DS- Desulfurization, T- Temperature $\left({ }^{\circ} \mathrm{C}\right), \mathrm{P}-$ Pressure, t- Time, $\mu \mathrm{m}$ - Micrometer 
Table 4. Demineralization/desulphurization of some low ash/sulfur coal

\begin{tabular}{|c|c|c|c|c|c|c|c|c|}
\hline $\begin{array}{l}\text { Sl } \\
\text { No }\end{array}$ & $\begin{array}{l}\text { Coal } \\
\text { Seams }\end{array}$ & $\begin{array}{l}\text { Coal type } \\
\text { and ash } \\
\text { and } \\
\text { sulphur } \\
(\%)\end{array}$ & $\begin{array}{l}\text { Coal } \\
\text { particle } \\
\text { size } \\
(\mu \mathrm{m})\end{array}$ & $\begin{array}{l}\text { Chemical } \\
\text { solvent } \\
\text { used }\end{array}$ & $\begin{array}{l}\text { The quantity } \\
\text { of coal and } \\
\text { Solvent } \\
\text { concentration }\end{array}$ & $\begin{array}{l}\text { Physical } \\
\text { parameter } \\
(\mathrm{T}, \mathrm{P}, \mathrm{t})\end{array}$ & $\begin{array}{l}\text { Demineralization/ } \\
\text { Desulfurization } \\
(\%)\end{array}$ & References \\
\hline 1 & $\begin{array}{l}\text { Nallihan, } \\
\text { Ankara, } \\
\text { Turkey }\end{array}$ & $\begin{array}{l}\text { Low ash } \\
(17.12 \% \\
\text { ash and } \\
6.99 \% \mathrm{~S} \\
\text { in } \\
\text { Nallihan } \\
\text { Lignite } \\
\text { coal }\end{array}$ & $250 \mu \mathrm{m}$ & $\begin{array}{l}\mathrm{HCl}, \\
\mathrm{HNO}_{3} \\
\mathrm{H}_{2} \mathrm{SO}_{4}, \\
\mathrm{HF}\end{array}$ & $\begin{array}{l}4 \mathrm{~g} \text { coal, } 80 \mathrm{ml} \\
\text { of } 5 \text { and } 10 \\
\text { vol\% of } \mathrm{HCl} \text {, } \\
\mathrm{HNO}_{3} \text {, } \\
\mathrm{H}_{2} \mathrm{SO}_{4}, \text { acid } \\
\text { and } \mathrm{HF} \text { of } 5 \text {, } \\
10,20,30, \\
\text { and } 40 \text { vol\% }\end{array}$ & $\begin{array}{l}20,40,50 \text {, } \\
\text { and } 60^{\circ} \mathrm{C} \\
\text { for } 20 \mathrm{~min}\end{array}$ & $\begin{array}{l}6.98 \% \text { ash obtained } \\
\text { by } 5 \% \mathrm{HF} \\
\text { treatment was best } \\
\text { other values are } \\
\text { sequenced as } \mathrm{HCl} \text {, } \\
\mathrm{HNO}_{3} \text {, and } \mathrm{H}_{2} \mathrm{SO}_{4} \\
\text { acid experiments }\end{array}$ & [55] \\
\hline 2 & $\begin{array}{l}\text { Tata } \\
\text { Steel's } \\
\text { captive } \\
\text { mines, } \\
\text { Coal A- } \\
\text { from } \\
\text { washery } \\
\text { and Coal } \\
\text { B-ROM }\end{array}$ & $\begin{array}{l}14.3 \text { and } \\
23 \% \text { ash }\end{array}$ & $-0.5 \mathrm{~mm}$ & $\begin{array}{l}\mathrm{NaOH}, \\
\mathrm{HCl}\end{array}$ & $\begin{array}{l}300 \mathrm{~g} \text { of coal } \\
\text { and } 30-40 \% \\
(\mathrm{w} / \mathrm{v}) \mathrm{NaOH}, \\
\text { maintain } 1: 10 \\
\text { ratio of } \\
\text { aqueous } \\
\text { solution later } \\
\text { washed } 20 \% \\
(\mathrm{v} / \mathrm{v}) \mathrm{HCl}\end{array}$ & $\begin{array}{l}85^{\circ} \mathrm{C} \text { and } \\
135^{\circ} \mathrm{C} \text { at } \\
\text { atmospheri } \\
\mathrm{c} \text { and } 5 \text { bar } \\
\text { pressure, } \\
4 \mathrm{hr}\end{array}$ & $\begin{array}{l}5.5 \% \text { ash produced } \\
\text { Coal A, coal B is } \\
7 \%, \text { Silica, and } \\
\text { alumina content } \\
\text { reduces by nearly } \\
51.3 \% \text { and } 58.8 \% \text {. }\end{array}$ & [56] \\
\hline 3 & $\begin{array}{l}\text { Coal } \\
\text { from } \\
\text { flotation } \\
\text { cell, } \\
\text { Tata } \\
\text { Steel, } \\
\text { India }\end{array}$ & $\begin{array}{l}\text { Low ash } \\
15.3 \% \\
\text { ash }\end{array}$ & $500 \mu \mathrm{m}$ & $\begin{array}{l}\mathrm{NaOH}, \\
\mathrm{HCl}\end{array}$ & $\begin{array}{l}30 \mathrm{~g} \text { coal, } \\
10 \% \text { to } 50 \% \\
\text { (w/v) varying } \\
\mathrm{S} / \mathrm{L} \text { ratio then } \\
\text { followed with } \\
10 \% \mathrm{HCl}(\mathrm{v} / \mathrm{v}) \\
\text { solution }\end{array}$ & $\begin{array}{l}\text { varying } \\
\text { residence } \\
\text { time, } \\
\text { temperature }\end{array}$ & $\begin{array}{l}\text { Ash content } \\
\text { reduced from } \\
\text { initial about } 8.85 \% \\
\text { by } \mathrm{NaOH} \\
\text { treatment and } \\
6.10 \% \text { by Alkali- } \\
\text { treated \& acid- } \\
\text { washed coal }\end{array}$ & [57] \\
\hline 4 & $\begin{array}{l}\text { Lakhra } \\
\text { coal, } \\
\text { Pakistan }\end{array}$ & $\begin{array}{l}10.5 \% \\
\text { ash, } \\
7.38 \% \\
\text { total } \\
\text { sulfur }\end{array}$ & $\begin{array}{l}-60 \\
\text { mesh, } \\
-80 \\
\text { mesh } \\
\text { and }-100 \\
\text { mesh }\end{array}$ & $\begin{array}{l}\mathrm{NaOH}, \\
\mathrm{HCl}, \\
\text { Purged } \\
\text { nitrogen } \\
(30 \mathrm{ml} / \mathrm{mi} \\
\text { n) }\end{array}$ & $\begin{array}{l}60 \mathrm{~g} \text { coal of } \\
\text { three mesh } \\
\text { size, in the } \\
\text { ratio } 1: 1,1: 2, \\
\text { and } 1: 3 \text { coals } \\
\text { to caustic } \\
\text { solution. }\end{array}$ & $\begin{array}{l}250^{\circ} \mathrm{C}, 60 \\
\text { min, } \\
\text { atmospheri } \\
\text { c pressure }\end{array}$ & $\begin{array}{l}\text { Removal of ash to } \\
\text { up to } 80 \% \text { and } \\
\text { sulfur to about } \\
40 \% \text {. }\end{array}$ & [58] \\
\hline
\end{tabular}

DM- Demineralization, DS- Desulfurization, T- Temperature $\left({ }^{\circ} \mathrm{C}\right), \mathrm{P}$ - Pressure, t- Time, $\mu \mathrm{m}$ - Micrometer

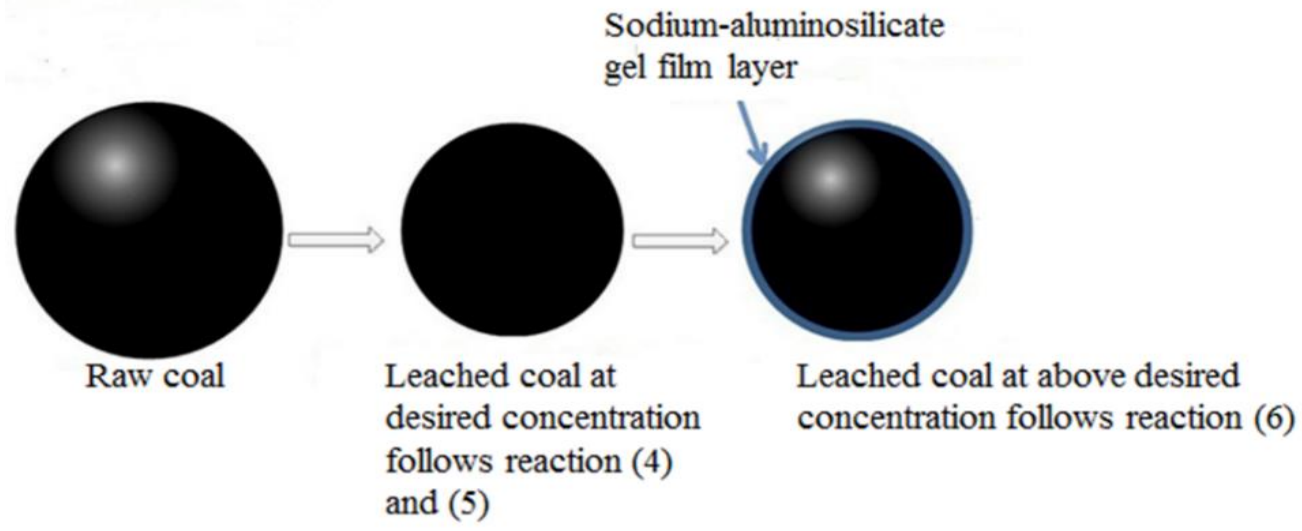

Figure 2. Mechanism of gel formation during leaching process [48] 
The following reactions (10) and (11) indicate the part of pyrite and organic sulfur can remove during alkali treatment.

$30 \mathrm{NaOH}+8 \mathrm{FeS}_{2} \rightarrow 4 \mathrm{Fe}_{2} \mathrm{O}_{3}+14 \mathrm{Na}_{2} \mathrm{~S}_{2} \mathrm{O}_{3}+15 \mathrm{H}_{2} \mathrm{O}$

$2 \mathrm{NaOH}+\mathrm{R}-\mathrm{S} \rightarrow \mathrm{R}-\mathrm{SNa}_{2}$

Numerous researchers [62-63] stated the demineralization of coal with an aqueous alkali solution. Wang et al., (1986) investigated that the removal of mineral matter from Miler Blend (high ash, 15.5\%) and Wandon (low ash, 7\%) coal of Australia by treatment with the alkali solution at $460 \mathrm{~K}$. The researchers showed that it is easier to reduce mineral rich components like quartz and kaolinite by alkali treatment although the elimination of $\mathrm{Ca}$ and $\mathrm{Fe}$ bearing mineral depends on the type of composition in coal [64].

Waugh (1984) reported that the most of the ash forming minerals from bituminous coal are insoluble in water or acid, while $90 \%$ of the mineral can be removed by caustic treatment, at $200{ }^{\circ} \mathrm{C}$ to $300{ }^{\circ} \mathrm{C}$ under pressure. They reported from the experimental results, most of the major minerals (like silica and kaolinite) is converted into sodium aluminosilicates (or at higher temperature forms sodalities, zeolites) which form a distinct insoluble phase in interaction with water or alkali, but which are readily dissolute in mineral acids. The low mineral content and trace elements are also partly liberated during leaching [65]. Removal of the pyritic sulfur and some of the organic sulfur by caustic wash was studied by Çulfaz et al., F(1996) applied two diverse lignite coal from Soma (low ash coal) and Beypazari (high ash coal), of Turkey. The maximum mineral was about $90 \%$ removed from both types of coal at high temperature $(460 \mathrm{~K})$ by caustic leaching followed with acid washing. In addition, they reported with decrease the particle size from 0.9 to $0.16 \mathrm{~mm}$, which causes the ash reduction was increased from 70.6 to $80.1 \%$ by the leaching process [66].

Mukherjee and Borthakur (2003) studied the leaching effect of $\mathrm{KOH}$ on coal samples from Boragolai and Ledo collieries of Makum coal fields, Assam. They reported demineralization and desulphurization were obtained $2-19 \%$ and $16-30 \%$ at $95^{\circ} \mathrm{C}$ and $150^{\circ} \mathrm{C}$ from the coal by the effect of potassium hydroxide solution. The degree of demineralization of the coal decreases with higher temperature $\left(150 \quad{ }^{\circ} \mathrm{C}\right)$ while desulphurization increases to $26-43 \%$. The demineralization was decreased due to increase the precipitation of potassium aluminosilicates, and it restricts the leaching process, later the precipitation was dissolute by the acid washing of $10 \%$ hydrochloric acid concentration. This treatment nearly removed the inorganic sulfur completely, and up to $37 \%$ organic sulfur was removed from the coal [67]. Balaz et al., (2001) investigated the chemical cleaning of coal by grinding and aqueous caustic leaching (GACL) process. In GACL process, the two different coals from Novaky $(28.2 \%$ ash, $2 \%$ sulfur $)$ and Pittsburgh No. Eight (7\% ash and 3\% sulfur) were treated with $5 \% \mathrm{NaOH}$ concentration. They reported the percentage of sulfur was reduced to $1.5 \%$ and $0.9 \%$ for both coal and deashing of coal was not improved by the leaching effect. This was due to the glass wear while grinding and alkaline chemical leaching (GACL) process, which contributes the ashforming constituents in the treated coal [68]. They found from the investigation; the GACL process is the best favour of economic suitable and high ash removal efficiency as compared to the MCL (molten caustic leaching) process because in GACL process the consumption of $\mathrm{NaOH}$ concentration was six times less than MCL process. Lee and Shon (1997) investigated the combustion characteristics and structure of Korean anthracite and bituminous coal by leaching 
with molten caustic. The effect of caustic treatment was increased four times reactivity of anthracite coal and marginal increase in the reactivity of bituminous coal. The greater extent of ash and sulfur reduction were obtained during MCL process. This process was reduced to $70 \%$ and $60 \%$ sulfur and $85 \%$ and $99 \%$ of ash reduction from anthracite and bituminous coal [69]. Chriswell et al., (1989) and Chriswell et al., (1991) investigated an advanced chemical coal-cleaning process, it referred as MCL process. They reported the MCL process was removed about $90 \%$ of sulfur and over $95 \%$ of the ash-bearing minerals reduced from the coal. However, this process was loosed the original carbon content of coal due to the formation of unwanted carbonate byproducts, consumed a significant amount of caustic concentration and difficult to the regeneration of spent caustic solution [70-71].

The effective demineralization of coal is also possible by $\mathrm{Ca}(\mathrm{OH})_{2}$ leaching reagent as compared to other alkali reagents. The replacement of leaching agent $\mathrm{CaO}$ (lime) instead of $\mathrm{NaOH}$ are following the number of favourable features. The advantage of leaching by lime follows (1) less effect to the organic matter of coal (2) high corrosion resistant to the reactor and equipment materials and (3) low fouling effect was produced during the combustion or gasification process. Coal demineralization by $\mathrm{Ca}(\mathrm{OH})_{2}$ leaching is an effective method for removal of the major minerals, and the magnitude of deduction of the Ca-bearing products from coal was highly dependent on the experimental leaching conditions [72]. Wang et al., (1996) investigated the demineralization of Newstan coal seam from Australia treated with lime. They reported the coal leached with $5 \% \mathrm{CaO}$ at $340{ }^{\circ} \mathrm{C}$ for 120 $\mathrm{min}$, followed by the hydrochloric acid wash, the ash reduction result $76 \%$ was obtained in the meantime the ash content reduced from
$9.2 \%$ to $2.2 \%$ [73]. Wang and Tomita (1998) investigated four places of the coal seam and leached with $\mathrm{Ca}(\mathrm{OH})_{2}$ at $300{ }^{\circ} \mathrm{C}$, followed by dilute $\mathrm{HCl}$ concentration. The investigation suggested the ash contents declined from 8.8$15.4 \%$ to $1 \%$ of Blair, Newlands, Athol, and Warkworth coals, and for Ebenezer coal, it was decreased from $14.9 \%$ to $2.8 \%$ [74].

\subsection{Acid leaching}

Acid leaching makes the most significant effect on the demineralization of coal. This leaching process demineralizes some mineral like carbonates, $\mathrm{Fe}_{2} \mathrm{O}_{3}$, and sulfides, while it does not dissociate the clay-bearing minerals. Steel et al., (2001) investigated the leaching behaviour of the mineral matter in lowtemperature ashing (LTA) of Australian black coal by the effect $\mathrm{HF}$ and $\mathrm{HCl}$. They reported, $\mathrm{HCl}$ was dissolving simple compounds such as carbonates and phosphates, but it was less dissolute the clay minerals. HF can react with all types of mineral matter, except pyrite, and mostly all reaction products are water-soluble. The leachant soluble the major clay minerals and the aluminosilicate mineral compounds and other mineral matter but at higher HF concentration, most of the mineral forms insoluble compound like $\mathrm{CaF}_{2}, \mathrm{MgF}_{2}$ [75]. Hydrofluoric acid is a strong oxidizing agent due to the presence of fluorine atom, and it can easily react with the mineral matter of coal. It can effectively dissolve the quartz and kaolinite. Quartz is easily dissolute than kaolinite during HF treatment. Therefore, the degree of demineralization depends on the presence of quartz to kaolinite proportion in the coal. Steel and Patrick (2001) reported that the production of ultra-clean coal (UCC) by chemical demineralization of high volatile UK coal. These coals were leached with $\mathrm{HF}$ at leaching temperature $65^{\circ} \mathrm{C}$ and contact time 3 $\mathrm{h}$, followed by $\mathrm{HNO}_{3}$ at similar condition 
[76]. The ash content of coal reduced from $7.9 \%$ to $2.6 \%$ and $67 \%$ demineralization was obtained by HF treatment alone and successive treatment of HF-treated coal with $\mathrm{HNO}_{3}$, which decreases the ash content up to $0.63 \%$ by dissolution of residual mineral compounds such as $\left(\mathrm{CaF}_{2}, \mathrm{MgF}_{2}, \mathrm{AlF}_{3}\right.$, $\mathrm{NaAlF}_{4}$ ) and $\mathrm{FeS}_{2}$ (pyrite) from $\mathrm{HF}$ treatment. Mukherjee et al., (2001) investigated the effect of hydrogen peroxide and diluted sulfuric acid on the desulfurization and demineralization of coal from Makum Coalfield, Assam, India. The coal treated with $15 \%$ concentration of hydrogen peroxide at 25 ${ }^{\circ} \mathrm{C}$ and the results showed that over $76 \%$ pyritic sulfur, $70 \%$ sulfate sulfur and $5 \%$ organic sulfur and $14 \%$ ash reduced by this leaching effect. Again, the residual $\mathrm{H}_{2} \mathrm{O}_{2}$ treated coal was subsequent leached with $0.1 \mathrm{~N} \mathrm{H}_{2} \mathrm{SO}_{4}$ treatment results found that complete removal of inorganic sulfur, over $26 \%$ organic sulfur and $43 \%$ ash reduced from the coal. The large desulphurization was found due to the used sulfuric acid behaves like as a catalyst for the reaction between the oxygen and pyrite molecules [77].

Nabeel et al., (2009) studied the stepwise leaching of low-grade coal using $20 \%$ aqueous $\mathrm{NaOH}$ treatment followed by $10 \%$ $\mathrm{H}_{2} \mathrm{SO}_{4}$. The three-step leaching process effect on coal by using $1 \%$ or $5 \% \mathrm{NaOH}$ treatment followed with $1 \%$ or $5 \% \quad \mathrm{H}_{2} \mathrm{SO}_{4}$ was developed. The experimental investigation achieved more than $75 \%$ to $80 \%$ demineralization of coal, and various toxic elements were removed [78].

Steel et al., (2003) and Yang et al., (1985) investigated a two-stage leaching effect of aqueous $\mathrm{HF}$ followed by aqueous $\mathrm{HNO}_{3}$ were treated with UK bituminous coal of particle size $<62 \mu \mathrm{m}$ and was containing $5.0 \%$ ash by weight and $2.4 \%$ sulfur by weight. The ash and sulfur contents reduced to $0.2 \%$ ash and $1.3 \%$ sulfur from the original coal. Besides the calorific value $(\mathrm{CV})$ fallen from 31.5 to
$29.5 \mathrm{MJ} / \mathrm{kg}$, and the nitrogen content increased $2.0 \%$ to $2.8 \%$ by weight, due to the outbreak of the carbonaceous matrix throughout the $\mathrm{HNO}_{3}$ leaching and also dissolved the pyrite $[61,79]$. The reaction between pyrite and nitric acid is sensitive to temperature dependent and concentration of acid, which produce the different products under different condition. The possible reaction occurred during leaching effect explained by Yang et al., (1985) as follows.

$$
\begin{aligned}
& \mathrm{FeS}_{2}+2 \mathrm{HNO}_{3} \rightarrow \mathrm{Fe}\left(\mathrm{NO}_{3}\right)_{2}+\mathrm{H}_{2} \mathrm{~S}+\mathrm{S} \\
& 2 \mathrm{Fe}_{2}+6 \mathrm{HNO}_{3} \rightarrow 2 \mathrm{Fe}\left(\mathrm{NO}_{3}\right)+3 \mathrm{H}_{2} \mathrm{~S}+\mathrm{S}
\end{aligned}
$$

$6 \mathrm{FeS}_{2}+30 \mathrm{HNO}_{3} \rightarrow 3 \mathrm{Fe}_{2}\left(\mathrm{SO}_{4}\right)_{3}+3 \mathrm{H}_{2} \mathrm{SO}_{4}+30 \mathrm{NO}+12 \mathrm{H}_{2} \mathrm{O}$

The use of weak acids (EDTA and citric acid) showed the effective demineralization. Wijaya et al., (2011) had proven the use of weak acid like pyroligneous acid and citric acid for the preparation of ultra-clean coal by leaching method [80]. Except this, several researchers studied the leaching effect of major minerals from coals by the effect of organic acid. The review of dissolution behaviour towards silicate, carbonate and phosphate minerals with organic acid was reported by Lazo et al., (2017) [81]. The review stated that the silica (major minerals in the coal), carbonate and phosphate minerals were significantly dissolute in the low molecular organic acids. They also stated the acid like formic and acetic acid had effectively removed the minerals of group I and II elements and the acids like citric, oxalic, EDTA and salicylic acids reduced the transition metal and lanthanide-based minerals.

\subsection{Alkali-acid leaching}

The use of acid-alkali or alkali-acid leaching is an effective method for demineralization of coal. Several authors have reported the combined treatment method of coal. The mutual leaching process is a benefit 
to obtain a higher degree of demineralization, may be caused due to the dissolution of the unreacted part and residual minerals from the first stage treatment. The leaching agents like $\mathrm{NaOH}$ and $\mathrm{KOH}$ treated with coal particle which reacts with sulphur and major minerals in the coal (silica, alumina, kaolinite, dolomite, quartz) which form hydrated alkali compounds of silicate, aluminate. Then, it acidified with $\mathrm{H}_{2} \mathrm{SO}_{4}$ or $\mathrm{HCl}$ remove the unreacted minerals and complex compounds from the alkali treated coal. The unreacted product formed during alkali leaching may be due to the concentration of soluble ion exceeds than the solubility product of its byproducts, which results in decreases the solubilization of coal mineral. Later the residual formed to precipitate and adsorbed to coal surface, which results in restriction to further demineralization process. These byproducts are easily dissolute in the acidic leachant. Hence, the effective demineralization was possible during alkali followed acid or combine leaching methods.

The main difference between the use of acid-alkali or alkali-acid leaching was the possibility of efficient demineralization in both processes. The low grade coals are naturally associated with a major quantity of clay minerals, and these are highly composed of silica, alumina and other silica material bound with the coal matrix. The mineral-rich silica-alumina constituents of coal are highly reacted by the caustic leaching due to the high affinity of hydroxyl ion of leachant and formed soluble sodium hydrated silicate and aluminate and sodium aluminosilicate compounds in the solution. Later, the residual minerals from alkali treated coal easily dissolute in the acidic solution, in this way efficient demineralization was obtained by the alkali-acid leaching. While during acid-alkali leaching, the existence of clay mineral composition (silica, alumina and other forms of silica) of coal is increased because the concealed mineral forms of silica and alumina in coal matrix which are not soluble during acid leaching only soluble the iron and sulphur minerals which are less amount in the coal. Then these residual of acid treated coal followed with alkali leaching and which difficult to dissolute due to the high composition of silica-alumina minerals in the alkali concentration. On the other reason, the coal associated with the major amount of inorganic minerals (mostly silica, alumina), which are easily reacted with alkali reagents and the insoluble minerals of the residual coal from an alkali leaching, which are soluble in acidic treatment. Therefore, the alkali-acid leaching process is better than the acid-alkali leaching.

Molten caustic leaching (MCL) process is one of the effective technique for deashing of coal, which by remove pyritic and organic sulfur from fossil fuels. Duz et al., (2008) stated the effect of leaching of asphaltite from Turkey with molten sodium hydroxide and followed by mild acid [82]. Chemical demineralization and desulfurization of asphaltite increased with increase in alkali to asphaltite ratio and ash and total sulfur increases with leaching temperature and time. They reported that completely removal of pyritic sulfur, $70 \%$ organic sulfur and ash, and 70-79\% volatile matter from asphaltites by treated with alkali at $1: 1$ ratio at $400{ }^{\circ} \mathrm{C}$ for 45 min followed with $1 \mathrm{M} \mathrm{HCl}$ solution. The coal from Hazro field, Turkey leaching with molten caustic and the ash content reduced from $18.3 \%$ to $6.8 \%$ and $70 \%$ of combustible was recovered. It was also removed the total sulfur from 7.54 to $1.01 \%$ and volatile matter content from 47.80 to $12.41 \%$ respectively. In spite of this most of the inorganic sulfur and a significant portion of the organic sulfur were removed [83]. Dash et al., (2013) reported the physical beneficiated of coal leached with caustic solution followed by acid washing [84]. The extent of demineralization was 
improved by increase with reaction time, alkali concentration, temperature and the decrease of coal particle size. They also reported that minor amount of sulfur reduction and significant reduction of phosphorous from coal was observed during acid treatment.

Baruah and Khare (2007) investigated the leaching effect on two high sulphur and ash coal from the North-east region of India. The two coal samples were selected one from Baragolai coal seam with high organic sulfur and low ash and the other from Ledo coal seam with low organic sulfur and high ash coal from the Assam region. They reported the samples of different size fraction were desulfurized in an oxidative medium $\left(\mathrm{H}_{2} \mathrm{O}_{2}\right.$ and $\mathrm{HCOOH}$ ) followed by solvent extraction (dimethylformamide, DMF) and alkali $(\mathrm{NaOH})$ treatment separately. In an oxidative medium, Ledo and Baragolai coals were removed up to $28 \%$ and $18.5 \%$ of organic sulfur and $84 \%$ of inorganic sulfur respectively. After solvent extraction, the desulfurization increases for the oxidized Baragolai and Ledo coals up to 95 and $93 \%$ of inorganic sulfur and 31 and $23 \%$ organic sulfur respectively. It was observed during the investigation; the alkali treatment was completely removed the inorganic sulfur and a maximum of $33 \%$ and $26.4 \%$ organic sulfur removed from Baragolai and Ledo coals [85].

Doymaz et al., (2007) investigated the effect of sodium hydroxide in sequential leaching followed by numerous mineral acids such as $\mathrm{HNO}_{3}, \mathrm{H}_{2} \mathrm{SO}_{4}, \mathrm{HCl}$ and $\mathrm{HF}$ for removal of mineral matter from asphaltite. The investigation reported the optimum method for chemical cleaning of the asphaltite was $5 \% \mathrm{NaOH}$ followed by leaching with $10 \%$ $\mathrm{H}_{2} \mathrm{SO}_{4}$ and $40 \% \mathrm{HF}$ and result showed that $59.56 \%$ degree of demineralization was obtained. It was also seen from investigation the calorific value of coal increased with extent of demineralization and it increases to $20.86 \%$ from the parent coal [86].

\section{Application of clean coal}

The demineralization method is used for the production of ultra-clean from low ash coal, which is not achieved through the existing process. It also has been used to upgrade the low-grade coal by removing the mineral matter from coal, which enhanced the similar characteristics of high rank coal. The coal-bearing less than $1 \%$ ash called ultraclean coal, which obtained from the coal by removing all the mineral impurities by chemical leaching technique. White Mining Limited is currently running a pilot plant produced ultra-clean coal from Australian coal in the Hunter Valley of New South Wales, which is developed by CSIRO. The process consumables are mainly sulphuric acid, and lime; caustic soda is regenerated in the process.

The main application of chemical cleaned coal (ultra-clean coal) is used as fuel in an internal combustion engine (ICE), which used in advanced power technologies like direct firing in the gas turbine, or used as fuel when it mixing with LNG and diesel engine. This high-purity of coal can be used directly fired into gas turbines to provide electricity with high-efficiency, reduce the emission of pollutants from the power generation. The performance of ultra-clean coal (UCC) makes an environmentally preferable and alternative to use as feed in conventional coal power generation, which can emit fewer greenhouse gases to the environment.

\section{Conclusions}

The review of literature study has been revealed that the efficient demineralization was possible by chemical leaching technique. The efficient degree of demineralization depends on the leaching process conditions and type of minerals present in the coal.

The demineralization of coal by chemical beneficiation technique is a cost-effective 
compared to the conventional physical beneficiation techniques although the effective demineralization is not achieved by a physical method. This may be due to the not removal of associated or bound mineral and organic minerals from the coal matrix. However, chemical leaching method is the most efficiently demineralize both organic and inorganic minerals from the coal matrix. In another way, it could be possible to upgrade the low grade coals to high-grade by the combined approach in conjunction of the physical and chemical method for beneficiation of coal follows a great potential for significant reduction of mineral matters with less capital. There are still large research gaps to address the unknown phenomena regarding the behaviour of minerals and a suitable chemical reagent for dissolution of minerals in coal demineralization. The reason behind the natural coal origin varies from place to place and mineral composition changes during coalification. The effective demineralization for the production of clean coal must be necessary to develop the appropriate process which could be followed with optimized leaching experimental conditions. The selected appropriate solvents for the leaching process could have the low cost which easily available abundantly and the process may suitable to environment-friendly and economically feasible. However, more investigations are required for upgrading the low grade coals by leaching technique with acids, alkali and other chemical solvent at varying process condition and develop an appropriate process for generation of clean coal.

\section{References}

[1] Goto, K., Yogo, K, Higashii, T. (2013) A review of efficiency penalty in a coalfired power plant with post-combustion $\mathrm{CO}_{2}$ capture. Applied. Energy, 111, 710 720 .
[2] Yamauchi, Y., Akiyama, K. (2013) Innovative zero-emission coal gasification power generation project. Energy Procedia, 37, 6579-6786.

[3] Rubiera, F., Arenillas, A., Arias, B., Pis, J.J., Sua'rez-Ruiz, I., Steel, K.M., Patrick, J.W. (2003) Combustion behaviour of ultra clean coal obtained by chemical demineralization. Fuel, 82, 2145-2151.

[4] IEA, (2012) Coal information. International Energy Agency - Coal Industry Advisory Board, Paris Cedex.

[5] https://www.eia.gov/outlooks/ieo/pdf/048 4(2016).pdf

[6] Coal Directory of India, (2010) Coal Controller's Organization, Kolkata.

[7] Meshram, P., Purohit, B.K., Sinha, M.K., Sahu, S.K., Pandey, B.D. (2015) Demineralization of low grade coal - A review. Renewable and Sustainable Energy Reviews, 41, 745-761.

[8] Wu, Z., Steel, K. M. (2007) Demineralization of a UK bituminous coal using HF and ferric ions. Fuel, 86, 2194-2200.

[9] Ryberg, M.W., Owsianiak, M., Laurent, A., Hauschild, M.Z. (2015) Power generation from chemically cleaned coals: do environmental benefits of firing cleaner coal outweigh environmental burden of cleaning. Energy \& Environmental Science, 8, 2435-2447.

[10] Sriramoju, S.K., Lingam, R.K., Dash, P.S. (2017) Mechanism of a coal chemical-leaching process and recovery of spent chemicals: a pilot-scale study. International Journal of Coal Preparation and Utilization, 37, 293-302.

[11] Önal, Y., Ceylan, K. (1995) Effects of treatments on the mineral matter and acidic functional group contents of Turkish lignites. Fuel, 74, 972-977.

[12] Smoot, L.D. (1993) Fundamentals of Coal Combustion for clean and Efficient 
Use. Elsevier, Amsterdam, The Netherlands.

[13] Huggins, F.E. (2002) Overview of analytical methods for inorganic constituents in coal. International Journal of Coal Geology, 50, 169-214.

[14] Yu, D., Xu, M., Zhang, L., Yao, H., Wang, Q., Ninomiya, Y. (2007) Computer-controlled scanning electron microscopy (CCSEM) Investigation on the Heterogeneous Nature of Mineral Matter in six typical Chinese coals. Energy \& Fuels, 21, 468-476.

[15] Wijaya, N., Zhang, L. (2011) A Critical Review of Coal Demineralization and Its Implication on Understanding the Speciation of Organically Bound Metals and Submicrometer Mineral Grains in Coal. Energy \& Fuels, 25, 1-16.

[16] Bryers, R.W. (1996) Fireside slagging, fouling, and high-temperature corrosion of heat transfer surface due to impurities in steam-raising fuels. Progress in Energy and Combustion Science, 22, 29-120.

[17] Grigore, M., Sakurovs, R., French, D., Sahajawalla, V. (2008) Mineral matter in coals and their reactions during coking. International Journal of Coal Geology, 76, 301-308.

[18] Vassiliev, S.V., Vassileva, C.C., Baxter, D., Andersen, L.K. (2009) A new approach for the combined chemical and mineral classification of the inorganic matter in coal. 2: potential applications of the classification systems. Fuel, 88, 246254.

[19] Finkelman, R.B., Orem, W., Castranova, V., Tatu, C.A., Belkin, H.E., Zheng, B., Lerch, H.B., Maharaj, S.V., Bates, A.L. (2002) Health impacts of coal and coal use: possible solutions. International Journal of Coal Geology, 50, 425-443.

[20] Kolker, A. (2012) Minor element distribution in iron disulfides in coal: a geochemical review. International Journal of Coal Geology, 94, 32-43.

[21] Diehl, S.F., Goldhaber, M.B., Koenig, A.E., Lowers, H.A., Ruppert, L.F. (2012) Distribution of arsenic, selenium, and other trace elements in high pyrite Appalachian coals: evidence for multiple episodes of pyrite formation. International Journal of Coal Geology, 94, 238-249.

[22] Querol, X., Fernandez-Turiel, J., LopezSoler, A. (1995) Trace elements in coal and their behaviour during combustion in a large power station. Fuel, 74, 331-343.

[23] Vassiliev, S.V., Vassileva, C.C. (2009) A new approach for the combined chemical and mineral classification of the inorganic matter in coal. 1. Chemical and mineral classification systems. Fuel, 88, 235-245.

[24] Jankowski, J., Ward, C.R., French, D., Groves, S. (2006) Mobility of trace elements from selected Australian fly ashes and its potential impact on aquatic ecosystems. Fuel, 85, 243-256.

[25] Ward, C.R., French, D., Jankowski, J., Dubikova, M., Li, Z., Riley, K. (2009) Element mobility from fresh and longstored acidic fly ashes associated with an Australian power station. International Journal of Coal Geology, 80, 224-236.

[26] Carlson, C.L., Adriano, D.C. (1993) Environmental impacts of coal combustion residues. Journal of Environmental Quality, 22, 227-247.

[27] Mie, R.J. (1994) Trace element behavior in coal-fired power plants. Fuel Processing Technology, 39, 199-217.

[28] Swaine, D.J. (1990) Trace elements in coal. Butterworths, London.

[29] Vassilev, S.V., Kitano, K., Vassileva, C.G. (1996) Some relationships between coal rank and chemical and mineral composition. Fuel, 75, 1537-1542. 
[30] Vassilev, S.V., Vassileva, C.G. (1996) Occurrence, abundance and origin of minerals in coals and coal ashes. Fuel Processing Technology, 48, 85-106.

[31] Akers, D., Dospoy, R. (1994) Role of coal cleaning in control of coal toxics. Fuel Processing Technology, 39, 73-86.

[32] Kelly, E.G., Spottiswood, D.J. (1989) The theory of electrostatic separations: a review- Part I, fundamentals. Minerals Engineering, 2, 33-46.

[33] Behera, S.K., Chakraborty, S., Meikap, B.C. (2016) Demineralization study of low grade Indian coal by aqueous caustic leaching. Recent Advances in Chemical Engineering. Springer, Singapore,99-08.

[34] Kumar, M., Gupta, R.C. (1997) Demineralization study of Indian Assam coking coal by sodium hydroxide leaching. Energy sources. Part A, Recovery, Utilization and Environmental Effects, 19, 723-730.

[35] Kumar, M., Shankar, R.H. (2000) Removal of ash from Indian Assam coking coal using sodium hydroxide and acid solutions. Energy sources. Part A, Recovery, Utilization and Environmental Effects, 22, 187-196.

[36] Mukherjee, S., Borthakur, P.C. (2003) Effect of leaching high sulfur sub bituminous coal by potassium hydroxide and acid on removal of mineral matter and sulfur. Fuel, 82, 783-788.

[37] Paul, M., Seferinoglu, M., Ayçik, G.A., Sandström, A., Smith, M.L., Paul, J. (2006) Acid leaching of ash and coal: time dependence and trace element occurrences. International Journal of Mineral Processing, 79, 27-41.

[38] Vasilakos, N.P., Clinton, C.S. (1984) Chemical beneficiation of coal with aqueous hydrogen peroxide/sulphuric acid solutions. Fuel, 63, 1561-1563.

[39] Behera, S.K., Chakraborty, S., Meikap, B.C. (2017) Up-gradation of low grade coal to high quality coal by chemical beneficiation technique. ASME, ASME Power Conference, Vol. 1, Fuels, Combustion and Material Handling; pp. V001T04A006. doi:10.1115/POWERICOPE2017-3057.

[40] Manoj, B. (2012) Chemical demineralization of high volatile Indian bituminous coal by carboxylic acid and characterization of the products by SEM/EDS. Journal of Environmental Research And Development, 6, 653-659.

[41] Sharma, D.K., Gihar, G. (1991) Chemical cleaning of low grade coals through alkali-acid leaching employing mild conditions under ambient pressure. Fuel, 70, 663-665.

[42] Rodriguez, R.A., Jul, C.C., Limon, D.G. (1996) The influence of process parameters on coal desulfurization by nitric leaching. Fuel, 75, 606-612.

[43] Choudhury, R., Bhaktavatsalam, A.K. (1997) Beneficiation of Indian coal by chemical techniques. Energy Conversion Management, 38, 173-178.

[44] Hamamci, C., Kahraman, F., Diiz, M.Z. (1997) Desulfurization of southeastern Anatolian asphaltites by the Meyers method. Fuel Processing Technology, 50, 171-177.

[45] Bolat, E., Saglam, S., Piskin, S. (1998) Chemical demineralization of a Turkish high ash bituminuous coal. Fuel Processing Technology, 57, 93-99.

[46] Sonmez, O., Giray, E.S. (2001) The influence of process parameters on desulfurization of two Turkish lignite's by selective oxidation. Fuel Processing Technology, 70, 159-169.

[47] Adeleke, A.A., Ibitoye, S.A., Afonja, A.A. (2013) Multistage caustic leaching desulphurization of a high sulphur coal. Petroleum \& Coal, 55, 112-117.

[48] Behera, S.K., Chakraborty, S., Meikap, B.C. (2017) Chemical demineralization 
of high ash Indian coal by using alkali and acid solutions. Fuel, 196, 102-109.

[49] Karaca, H., Ceylan, K. (1997) Chemical cleaning of Turkish lignites by leaching with aqueous hydrogen peroxide. Fuel Processing Technology, 50, 19-23.

[50] Ratanakandilok, S., Ngamprasersith, S., Prasassarakich, P. (2001) Coal desulfurization with methanol/water and methanol/KOH. Fuel, 80, 1937-1942.

[51] Ishaq, M., Ahmad, I., Shakirulla, M., Bahader, A., Taj, N. (2002) Characterization of Khushab coal. Journal of the Chemical Society of Pakistan, 24, 240-245.

[52] Baruah, B.P., Saikia, B.K., Kotoky, P., Rao, P.G. (2006) Aqueous leaching on high sulfur subbituminous coals, in Assam, India. Energy \& Fuels, 20, 15501555.

[53] Kizgut, S., Baris, K., Yilmaz, S. (2006) Effect of chemical demineralization on thermal behavior of bituminous coals. Journal of Thermal Analysis and Calorimetry, 86, 483-488.

[54] Liu, K., Yang, J.J., Wang, J.J. (2008) Desulfurization of coal via low temperature atmospheric alkaline oxidation. Chemosphere, 71, 183-188.

[55] Gulen, J., Doymaz, I., Piskin, S., Ongen, S. (2013) The effects of temperature and mineral acids on the demineralization degree of Nallihan lignite. Energy sources. Part A, Recovery, Utilization and Environmental Effects, 35, 202-208.

[56] Dash, P.S., Lingam, R.K., Kumar, S.S., Suresh, A., Banerjee, P.K., Ganguly, S. (2015) Effect of elevated temperature and pressure on the leaching characteristics of Indian coals. Fuel, 140, 302-308.

[57] Dash, P.S., Sriramoju, S.K., Kargupta, K., Banerjee, P.K., Ganguly, S. (2015) Characterization of chemically beneficiated Indian coals. International
Journal of Coal Preparation and Utilization, 35, 257-272.

[58] Wahab, A., Nawaz, S., Shahzad, K., Akhtar, J., Kanwal, S., Munir, S., Sheikh, N. (2015) Desulfurization and demineralization of lakhra coal by molten caustic leaching. Energy sources. Part A, Recovery, Utilization and Environmental Effects, 37, 1219-1223.

[59] Mukherjee, S., Borthakur, P.C. (2001) Chemical demineralization/ desulfurizetion of high sulfur coal using sodium hydroxide and acid solutions. Fuel, 80, 2037-2040.

[60] Behera, S. K., Meena, H., Chakraborty, S., Meikap, B. C. 2018. Application of response surface methodology (RSM) for optimization of leaching parameters for ash reduction from low-grade coal. International Journal of Mining Science \& Technology, 28 (4), 621-629.

[61] Yang, R.T., Das, S.K., Tsai, B.M.C. (1985) Coal demineralization using sodium hydroxide and acid solutions. Fuel, 64, 735-742.

[62] Kara, H., Ceylan, R. (1988) Removal of sulfur from four central Anatolian lignites by $\mathrm{NaOH}$. Fuel, 67, 170-172.

[63] Saydut, A., Duz, M.Z., Erdogan, S., Tonbul, Y., Hamamci C. (2011) Chemical leaching on Sulfur and mineral matter removal from asphaltite (Harbul, SE Anatolia, Turkey). Energy sources. Part A, Recovery, Utilization and Environmental Effects, 33, 383-391.

[64] Wang, Z.Y., Ohtsuka, Y., Tomita, A. (1986) Removal of mineral matter from coal by alkali treatment. Fuel Processing Technology, 13, 279-289.

[65] Waugh, A.B., Bowling, K.M. (1984) Removal of mineral matter from bituminous coals by aqueous chemical leaching. Fuel Processing Technology, 9, 217-233. 
[66] Culfaz, M., Ahmed, M., Gurkan, S. (1996) Removal of mineral matter and sulfur from lignites by alkali treatment. Fuel Processing Technology, 47, 99-109.

[67] Mukherjee, S., Borthakur, S. (2003) Demineralization of subbituminous high sulphur coal using mineral acids. Fuel Processing Technology, 85, 157-164.

[68] Balaz, P., LaCount, R.B., Kern, D.G., Turcaniova, L. (2001) Chemical treatment of coal by grinding and aqueous caustic leaching. Fuel, 80, 665671.

[69] Lee, S.H., Shon, E.K. (1997) Effect of molten caustic leaching on the combustion characteristics of anthracite. Fuel, 76, 241-246.

[70] Chriswell, C.D., Shah, N.D., Kaushik, S.M., Markuszewski, R. (1989) Chemical cleaning of coal by molten caustic leaching after pretreatment by lowtemperature devolatilization. Fuel Processing Technology, 22, 25-39.

[71] Chriswell, C.D., Shah, N.D., Markuszewski, R. (1991) Counter current washing of Pittsburgh No.8 coal after leaching with molten mixture of sodium and potassium hydroxides. Separation Science and Technology, 26, 961-975.

[72] Wang, J., Tomita, A., Taylor, G.H., Fitz, Gerald, J.D. (1997) Microscopic observation of coal demineralization by $\mathrm{Ca}(\mathrm{OH}) 2$ leaching. Fuel, 76, 369-374.

[73] Wang, J., Zhang, Z.G., Kobayashi, Y., Tomita, A. (1996) Chemistry of $\mathrm{Ca}(\mathrm{OH})_{2}$ leaching on mineral matter removal from coal. Energy \& Fuels, 10, 386-391.

[74] Wang, J., Tomita, A. (1998) Removal of mineral matter from some Australian coals by $\mathrm{Ca}\left(\mathrm{OH}_{22} / \mathrm{HCl}\right.$ leaching. Fuel, 77, 1747-1753.

[75] Steel, K.M., Besida J, O’Donnell T.A., Wood, D.G. (2001) Production of Ultra Clean Coal Part I-Dissolution behaviour of mineral matter in black coal toward hydrochloric and hydrofluoric acids. Fuel Processing Technology, 70, 171-192.

[76] Steel, K.M., Patrick, J.W. (2001) The production of ultra-clean coal by chemical demineralization. Fuel, 80, 2019-2023.

[77] Mukherjee, S., Mahiuddin, S., Borthakur, P.C. (2001) Demineralization and desulfurization of subbituminous coal with hydrogen peroxide. Energy \& Fuels, $15,1418-1424$.

[78] Nabeel, A., Khan, T.A., Sharma, D.K. (2009) Studies on the production of ultraclean coal by alkali-acid leaching of lowgrade coals. Energy sources. Part A, Recovery, Utilization and Environmental Effects, 31, 594-601.

[79] Steel, K.M., Patrick, J.W. (2003) The production of ultra clean coal by sequential leaching with HF followed by HNO3. Fuel, 82, 1917-1920.

[80] Wijaya, N., Choo, T.K., Zhang, L. (2011) Generation of ultra-clean coal from Victorian brown coal - Sequential and single leaching at room temperature to elucidate the elution of individual inorganic elements. Fuel Processing Technology, 92, 2127-2137.

[81] Lazo, D.E., Dyer, L.G., Alorro, R. D. (2017) Silicate, phosphate and carbonate mineral dissolution behaviour in the presence of organic acids: A review. Minerals Engineering 100, 115-123.

[82] Duz, M.Z., Erdogan, S., Saydut, A., Merdivan, M., Hamamci, C. (2008) Effect of molten caustic leaching on demineralization and desulfurization of asphaltite. Energy sources. Part A, Recovery, Utilization and Environmental Effects, 30, 1637-1644.

[83] Duz, M.Z., Saydut, A., Erdogan, S., Hamamci, C. (2009) Removal of sulfur and ash from coal using molten caustic 
leaching, a case study from hazro fields, Turkey. Energy Exploration \& Exploitation, 27, 391-400.

[84] Dash, P.S., Kumar, S.S., Banerjee, P.K., Ganguly, S. (2013) Chemical leaching of high ash Indian coals for production of low ash clean coal. Mineral Processing and Extractive Metallurgy Review, 34, 223-239.

[85] Baruah, B.P., Khare, P. (2007) Desulfurization of oxidized Indian coals with solvent extraction and alkali treatment. Energy \& Fuels, 21, 21562164.

[86] Doymaz, I., Gulen, J., Piskin, S. (2007) The effect of aqueous caustic and various acid treatments on the removal of mineral matter in asphaltite. nergy sources. Part A, Recovery, Utilization and Environmental Effects, 29, 337-346. 


\title{
PREGLED HEMIJSKOG LUŽENJA UGLJA U KISELOM I ALKALNOM RASTVORU
}

\author{
S.K. Behera ${ }^{1 \#}$, U. Kumari ${ }^{1}$, B.C. Meikap ${ }^{1,2}$ \\ ${ }^{1}$ Indian Institute of Technology (IIT) Kharagpur, Department of Chemical Engineering, \\ West Bengal-721302, India \\ ${ }^{2}$ Chemical Engineering, School of Engineering, Howard College, University of Kwazulu-Natal \\ (UKZN), Durban 4041, South Africa
}

(Primljen: 3. Mart 2018.; Prihvaćen: 11. Jun 2018.)

\begin{abstract}
Izvod
Niskokalorični ugljevi mogu se naći u izobilju u nekoliko regiona na svetu. On ima značajnu ulogu u energetskom sektoru $i$ kao hemijska sirovina $u$ industriji. Zalihe kamenog uglja postupno se iscrpljuju, a rudarske operacije $u$ dubljim ugljenim slojevima se odvijaju sa velikim poteškoćama, a i sami troškovi eksploatacije istraživanja su tako visoki, što bitno utiče na ekonomiju postrojenja. Stoga, niskokalorični ugalj može se koristiti kao alternativni izvor energije da bi se ovi problemi sveli na minimum. Niskokalorični ugljevi uglavnom sadrže veliki procenat minerala $i$ povećanu vlažnost, što značajno utiče na njihovu potrošnju, uključujući postupke pirolize, gasifikacije i likvefakcije $i$ sagorevanja. Suštinsko razumevanje postupka tretiranja uglja, za efikasno uklanjanje mineralnih materija $i$ za poboljšanje osobina uglja tehnikama oplemenjivanja, polazna je osnova za razvoj naprednih tehnologija. Ovaj članak pruža sveobuhvatni pregled različitih postupaka demineralizacije uglja putem hemijske tehnike oplemenjivanja. Tokom ovog istraživanja se došlo do zaključka da je stepen demineralizacije veći hemijskim postupcima oplemenjivanja u poređenju sa fizičkim oplemenjivanjem. Ovo iz razloga što hemijski reagensi napadaju unutrašnju strukturu uglja, a što dovodi do uklanjanja neorganskih materijala i fino dispergovanih minerala iz. strukture uglja. Hemijskim metodama izdvajaju se svi tipovi minerala iz uglja. Medjutim, separacija minerala fizičkim metodama zavisi od osobina minerala. Hemijsko oplemenjivanje luženjem je pogodan metod za redukovanje sadržaja i organskih i neorganskih konstituenata iz uglja. Hemijski reagensi difunduju u unutrašnju strukturu uglja, krećući se kroz pore i pritom razlažu minerale. Tokom ispitivanja, došlo se do zaključka da hemijsko čišćenje niskokaloričnog uglja predstavlja efikasnu tehniku za smanjenje sadržaja minerala na minimum, što omogućava njegovo obogaćivanje do uglja boljeg kvaliteta.
\end{abstract}

Ključne reči: niskokalorični ugalj; mineralna materija; oplemenjivanje; hemijski metod; demineralizacija.

\footnotetext{
${ }^{\#}$ Kontakt adresa autora: skbehera@che.iitkgp.ac.in
} 